NBER WORKING PAPER SERIES

\title{
WHY DID THE TARIFF-GROWTH CORRELATION REVERSE AFTER 1950?
}

\author{
Michael A. Clemens \\ Jeffrey G. Williamson \\ Working Paper 9181 \\ http://www.nber.org/papers/w9181 \\ NATIONAL BUREAU OF ECONOMIC RESEARCH \\ 1050 Massachusetts Avenue \\ Cambridge, MA 02138 \\ September 2002
}

We have received superb research assistance from István Zöllei. In addition, we are grateful to many who have helped in our search for country tariff and other data used in this paper: Luis Bertola, John Coatsworth, Bouda Etemad, David Feeny, Aurora Gomez, Paul Gregory, David Hummels, Doug Irwin, Pedro Lains, Peter Lindert, Ian McLean, Anna Maria Mayda, Sevket Pamuk, Dwight Perkins, Gunnar Persson, Leandro Prados, Athanasios Vamvakidis, and Tarik Yousef. We also benefited by comments from Elhanan Helpman, Kevin O'Rourke, Dani Rodrik, Andrew Warner and participants in the Harvard Workshops in Economic History and International Economics, as well as from those attending the Sound Conference in Economic History (Copenhagen: March 1, 2002) and two anonymous reviewers. Remaining errors belong to us. Williamson acknowledges with pleasure financial support from the National Science Foundation SES-0001362, and both authors thank the Center for International Development for allocating office space to the project. The views expressed herein are those of the authors and not necessarily those of the National Bureau of Economic Research.

(C) 2002 by Michael A. Clemens and Jeffrey G. Williamson. All rights reserved. Short sections of text, not to exceed two paragraphs, may be quoted without explicit permission provided that full credit, including $($ ) notice, is given to the source. 
Why Did the Tariff-Growth Correlation Reverse After 1950 ?

Michael A. Clemens and Jeffrey G. Williamson

NBER Working Paper No. 9181

September 2002

JEL No. F1, N7, O1

\begin{abstract}
This paper uses a new database to establish a key finding: high tariffs were associated with fast growth before World War II, while associated with slow growth thereafter. The paper offers some explanations for the sign switch by controlling for novel measures of the changing world economic environment. Rejecting alternative explanations based on changing export market growth or transportation cost declines, it shows how the oft-quoted Sachs-Warner result might be turned on its head in a world environment characterized by a moderately higher level of generalized tariff protection. We confirm the spirit of recent findings by Rodrik and Rodríguez that postwar tariffs need not be negatively correlated with growth in an unconditional fashion. Just a $4 \%$ increase in average tariff rates among trading partners might suffice to reverse any negative relationship between an average country's tariffs and its growth. An increase in own tariffs after 1970 hurt or at least didn't help growth, but it would have helped growth in a world where average trading partners' tariffs were moderately higher. The world environment matters. Leader-country reaction to big world events matters.
\end{abstract}

Michael A. Clemens

Center for Global Development

1776 Massachusetts Ave. NW, Suite 301

Washington, DC 20036

mclemens@cgdev.org
Jeffrey G. Williamson

Department of Economics

Harvard University

Cambridge MA 02138

and NBER

and Center for International Development

jwilliam@kuznets.harvard.edu 


\section{The Tariff-Growth Connection}

Does protection help growth? While theory may be ambiguous, late $20^{\text {th }}$ century evidence certainly is not. This evidence can be found in four kinds of studies. ${ }^{1}$

First, the authors of a large National Bureau of Economic Research project assessed trade and exchange-control regimes in the 1960s and 1970s by making classic partial-equilibrium calculations of deadweight losses (Bhagwati and Krueger 1973-1976). They concluded that the barriers imposed significant costs in all but one case. However, these standard welfare calculations have been criticized by those who have pointed out that protection in such studies is not allowed a chance to lower long-run cost curves, as in the traditional infant-industry case, or to foster industrialization and thus growth, as in those modern growth models where industry is the carrier of technological change and capital deepening. Thus, economists have had to look for more late $20^{\text {th }}$ century proof to support the openness-fosters-growth hypothesis.

Second, analysts have contrasted the growth performance of relatively open with relatively closed economies. The World Bank has conducted such studies for 41 countries going back before the first oil shock. The correlation between trade openness and growth is abundantly clear in these studies (Lindert and Williamson 2001: Table 3), but the analysis is vulnerable to two criticisms. Assigning countries to trade policy categories is always tricky, since it is hard to measure overall openness (Anderson and Neary 1994; Sachs and Warner 1995). More importantly, it is difficult to isolate the effect of trade policies alone, since other policies usually change at the same time. Liberalism typically comes as a package. Thus, countries that liberalized their trade also liberalized their domestic factor markets, liberalized their domestic commodity markets, and set up better property-rights enforcement. The appearance of these

\footnotetext{
${ }^{1}$ This section draws on a recent survey paper by Peter Lindert and Jeffrey Williamson (2001: pp. 21-25). We choose to focus on growth effects, in the context of a well-developed literature on postwar trade and growth. We are aware, however, of a younger literature on the relationship between trade and levels of wealth (notably in Frankel and Romer 1999, extended back to 1913 by Irwin and Terviö 2002).
} 
domestic policies may deserve more credit for raising income while the simultaneous appearance of more liberal trade policies may deserve less.

Third, there are country event studies, where the focus is on periods when trade policy regimes change dramatically enough to see their effect on growth. For example, Anne Krueger $(1983,1984)$ looked at trade opening moments in South Korea around 1960, Brazil and Colombia around 1965, and Tunisia around 1970. Growth improved after liberalization in all four cases. More recently, David Dollar and Aart Kraay (2000) examined the reforms and trade liberalizations of 16 countries in the 1980s and 1990s, finding, once again, the positive correlation between freer trade and faster growth. Of course, these reform episodes may have changed more than just global participation, so that an independent trade effect may not have been isolated.

Fourth, macro-econometric analysis has been used in an attempt to resolve the doubts left by simpler historical correlations revealed by the other three kinds of studies. This macro-econometric literature shows that free trade policies have had a positive effect on growth in the late $20^{\text {th }}$ century, especially with many other relevant influences held constant. The most famous of these is by Jeffrey Sachs and Andrew Warner (1995), but many others have also confirmed the openness-fosters-growth hypothesis for the late $20^{\text {th }}$ century (e.g. Dollar 1992; Edwards 1993; Harrison 1996; Bloom and Williamson 1998; Dollar and Kraay 2000; Greenaway, Morgan and Wright 2002).

This literature has been heavily criticized for omitting other policy variables from the analysis that may affect growth and be correlated with tariff policy. The point has been made recently and prominently by Francisco Rodríguez and Dani Rodrik (2001) who question whether some of the late $20^{\text {th }}$ century results would be so unequivocal if they controlled more carefully for these omitted policies. Rodríguez and Rodrik believe that there has been a tendency to overstate the pure tariff effect on growth. We believe that pre-1950 history supports them. 


\section{Country Tariff Experience 1865-1950}

While economists know trade policy experience since 1950 well enough, they do not know the pre-1950 experience quite so well. They should know it better. Figure 1 plots the worldwide own tariff average between 1865 and 1996 for a sample of 35 countries used throughout this paper. Figure 2 plots it for some regional clubs between 1865 and $1950 .{ }^{2}$ There are four regional clubs plotted there-Core, European Periphery, Rich European Offshoots and LDCs—-the country members of which are: 4 members of the industrial Core (France, Germany, UK, US); 7 rich European Offshoots (Argentina, Australia, Canada, Chile, Cuba, New Zealand, Uruguay); 10 from the European Periphery (Austria-Hungary, Denmark, Greece, Italy, Norway, Portugal, Russia, Serbia, Spain, Sweden); and 14 less developed countries (LDCs) in Asia, the Mideast and Latin America (Brazil, Burma, Ceylon, China, Colombia, Egypt, India, Indonesia, Japan, Mexico, Peru, the Philippines, Siam, Turkey). ${ }^{3}$ Table 1 uses the average tariff rate as our measure of protection. There is, of course, a well-developed literature that debates how to measure openness (e.g., Anderson and Neary 1994; Sachs and Warner 1995; O’Rourke 1997; Anderson 1998). That literature makes it clear that trade share measures must be rejected since they are so obviously endogenous. Among the exogenous policy measures available, the average tariff rate is the easiest to collect, ${ }^{4}$ and we use it here.

\footnotetext{
${ }^{2}$ We also have calculated the regional weighted averages for both Figures 1 and 2, where weights are the country's total export share in regional exports. The text story is not significantly changed, and we prefer to treat countries as independent policy units regardless of size. The complete data base used in this paper is described at length in the Appendix.

${ }^{3}$ We do not have coverage of all countries in all years for all variables, resulting in sample sizes that vary depending on the years and regressors included.

${ }^{4}$ The average tariff rate is measured here as customs revenues (import duties only) as a share of total import values. We use the phrase "exogenous tariff policy" here, but we are very aware of the flourishing endogenous tariff literature. Indeed, we have used our data base to contribute to that literature in two recent working papers (Coatsworth and Williamson 2002: Blattman, Clemens and Williamson 2002).
} 
The first thing to note is the powerful role played by inflations and deflations in the past. Import duties were typically specific until modern times, quoted as pesos per bale, yen per yard, or dollars per bag. Obviously, abrupt changes in price levels would change import values in the denominator, but not the legislated specific duty in the numerator, thus producing big equivalent ad valorem rate changes, that is big changes in percentage rates. Ad valorem rates are more common today, so that equivalent tariff rates are less affected by inflation and deflation. ${ }^{5}$ The impact of inflations during the two world wars were quite spectacular, and they had nothing to do with policy (except status quo ante). Thus, the tariff rates in all four regions fell sharply between 1914 and 1919, and again between 1939 and 1947. Part of the rise in tariffs immediately after World War I was also due to post-war deflation and the partial attainment of prewar price levels. The price deflation after 1929 was even more spectacular, and it too served to raise tariffs rates at least on duties that were still specific (import values now declining). The process repeats during the World War II inflations, but, in contrast, there is no sign of resumption of the very high rates attained in the 1930s.

Second, note in Figure 1 the protectionist drift worldwide between 1865 and World War I, a modest anti-globalization backlash if you will, registering a slow retreat from the liberal pro-global trade positions in mid-century (Williamson 1998).

Third, note too the enormous variance in tariff levels between the regional club averages. There was, of course, even greater variance within these regional clubs. In 1905, tariffs in Uruguay (the most protectionist Rich European Offshoot) were about two and a half times those in Canada (the least). In the same year, tariffs in Brazil and Colombia (the most protectionist LDCs) were almost ten times those in

\footnotetext{
${ }^{5}$ We are certainly not the first to notice this effect. Douglas Irwin has made the same point in accounting for US tariff experience between the Civil War and the Great Depression where "roughly two-thirds of dutiable U.S. imports were subject to specific or compound duties ..." (Irwin 1998: p. 1017). Although it fell in the $20^{\text {th }}$ century, the share was still half by the mid-1960s. A compound duty refers to one that imposes both specific and ad valorem duties on a given import good.
} 
China and India (the least). The same high-low range appeared in the Core (the US five times the UK) and the European Periphery (Russia six times Austria-Hungary). The empirical analysis later in this paper will treat countries as the unit of observation, but for now let's simply look at the regional clubs.

Prior to World War I, tariffs were much higher in the Rich European Offshoots than anywhere else. Furthermore, they would have been even higher had we allocated to this club one of the mostprotectionist, the US (which is allocated instead to the Core). ${ }^{6}$ The European members of the Core (France, Germany, UK) had the lowest tariffs, although the US serves to raise the club average. Much of the LDC club members were colonies of the Core (Burma, Ceylon, Egypt, India, Indonesia, the Philippines), or were forced to sign free trade agreements with the Core since the latter had naval guns trained on their potential trading partners (China, Japan), or viewed nearby gunboats as a sufficient threat to go open on their own (Siam). Thus, the LDC tariff rates are pretty much like those of the Core early on, but they start drifting towards high tariffs in the 1890s, long before the African and Asian independence movement after World War II. This protectionist drift is due to events in poor Latin America (Brazil, Colombia, Mexico) as well as in Egypt, Japan, and Turkey (late Ottoman). In 1865, the LDCs had the lowest tariffs, while in 1914 they were second to the Rich European Offshoots. The European Periphery leaps to high tariffs after the 1870 s, with Russian protectionist policy leading the way. There is plenty of evidence of rising world tariffs before World War I (the unweighted average in the full sample rising from about $12 \%$ in 1865 to about $17 \%$ in 1910), and this drift appeared everywhere except the Core (although the slow drift away from high tariffs is driven entirely by the slow US retreat from its enormous Civil War tariffs), but it took place mainly in the Rich European Offshoots and the European Periphery. There is also

\footnotetext{
${ }^{6}$ The US has always presented a problem to historians and economists alike. The canonical frontier economy with scarce labor and abundant resources, by 1900 it was the world's industrial leader (Wright 1990) and a central market for the exports from the rest of the world, especially Latin America. So, while the US was certainly a Rich European Offshoot, we allocate it to the Core. Re-running the analysis of Table 3 with the US assigned to "Rich European Offshoot" instead of "Core" increases the value of the coefficient on own tariffs and decreases the coefficient on the own tariff-Rich European Offshoot dummy interaction, but does not change any of the substantive conclusions we
} 
evidence of a worldwide reversal of the pre-war drift towards higher tariffs after about 1900, but it did not include the LDCs which bucked the tide (led by Brazil, Colombia, Japan and the Philippines).

In the interwar decades, tariffs took two big leaps upward, and these took place world wide. The first leap was in the 1920s, which might be interpreted as a policy effort to return to 1914 levels. The second was in the 1930s, with aggressive beggar-my-neighbor policies reinforced by the specific-dutydeflation effect. While tariffs shot up everywhere, the rank order of the four clubs changed considerably. In 1914, and from high tariffs to low, the rank order was Rich European Offshoots, LDCs, European Periphery, and Core. In 1939, it was a tie between Core, Rich European Offshoots, and LDCs—all now matching the very high levels of tariffs reached by the Rich European Offshoots in the 1890s, and the less protectionist European Periphery—which had about regained its pre-war levels. This rank order made another even more important change after World War II: the LDCs rose to the top of the heap and the Rich European Offshoots dropped below both the LDCs and the Core.

Figure 3 plots a principal-trading-partners'-tariff index for the same regional clubs. It is calculated as follows: first, we identify for each country which countries are its major trading partners (up to five); second, we calculate exports going to each major trading partner as a share of total country exports going to all major trading partners; third, we use these shares as weights by which to construct the average tariff faced by each country. Finally, we construct an unweighted average for each region. ${ }^{7}$

Figure 3 tells us that in the two decades before World War I, every region faced lower tariff rates in their main export markets than they themselves erected against competitors in their own markets. The explanation, of course, is that the main export markets were located in the Core, where tariffs were much lower. Thus, the Periphery faced lower tariffs than did the Core (for the European Periphery this was true

draw from Table 2 or any of the further analysis of regional effects.

${ }^{7}$ Figure 3 has also been constructed as a weighted average where the averages weight these indices by share of each country's exports in total regional club exports. It does not change the story much. See footnote 2. 
throughout, but for the LDCs it was true only up to just before 1900, when the US replaced Britain as a major export market for them). During the interwar, every club faced very similar tariff rates in export markets, but those rates were rising very steeply as the Core made the biggest policy switch—compared with the other three clubs- from free trade to protection.

\section{A Reversal in the Tariff-Growth Correlation?}

About thirty years ago, Paul Bairoch (1972) argued that protectionist countries grew faster in the $19^{\text {th }}$ century, not slower as every economist has found for the late $20^{\text {th }}$ century. Bairoch's sample was European, it looked at pre-1914 experience only, and it invoked unconditional analysis, controlling for no other factors. Like the second group of modern studies listed above, it simply compared growth rates of major European countries in protectionist and free trade episodes. More recently, Kevin O'Rourke (2000) got the Bairoch finding again, this time using macro-econometric conditional analysis on a ten country sample drawn from the pre-1914 Atlantic economy (Australia, Canada, Denmark, France, Germany, Italy, Norway, Sweden, UK, US). In short, these two scholars were not able to find any evidence before World War I supporting the openness-fosters-growth hypothesis. Another recent study (Vamvakidis 2002) could find no interwar evidence supporting the openness-fosters-growth hypothesis either, although it was (once again) based on a small, mostly OECD sample. ${ }^{8}$

These pioneering historical studies suggest that the Tariff-Growth Paradox should be taken seriously. Was there a regime switch somewhere between the start of World War I and the end of World War II, and, if so, when? If free trade has encouraged (or at least has not harmed) growth since World War

\footnotetext{
${ }^{8}$ There are two other studies worth mentioning here. Capie (1983) explored the Bairoch hypothesis with a pre-1914 European sample of four (Germany, Italy, the UK and Russia), using event analysis. Alfred Eckes (1995) attempted to establish causation from high tariffs to fast growth for $19^{\text {th }}$ century United States, although his work is assiduously criticized by Irwin (2001).
} 
II, why was it bad for growth before? Nobody has yet performed the test using the same model, and with a country sample that covers the whole world and for the period from the liberal and pro-global mid-19 century to the present.

This paper will further explore whether the Paradox persisted the world around, or whether instead there was asymmetry between rich industrial economies in the Core and poor agricultural economies in the Periphery. Presumably, the protecting country has to be ready for industrialization, accumulation, and human capital deepening if the long run tariff-induced dynamic effects are to offset the short run gains from trade given up. We test the asymmetry hypothesis by asking whether the Paradox persisted for all regions, industrial and primary-product producing. The paper will also ask whether the tariff policies of trading partners mattered. Were high tariffs at home matched by high tariffs abroad, and did it matter? Also, did trading partners' GDP growth improve performance at home? It might be argued that conditions were less auspicious for trade liberalization as a means of achieving industrialization before 1940 since there were so few fast-growing export markets for manufactures. A policy of relying on domestic markets empty of foreign competitors might have had more going for it then. The parallel argument today would be that although there are fast-growing world markets for manufactures, there are also so many competitors in those markets that industrial late-comers—like Latin America—suffer, while East Asia benefited by going open early without many competitors. Historical timing matters, and this fact might help explain the Paradox.

Table 1 offers such a test for our world sample of 35 high and low income countries. The model estimated there is of the convergence variety, but only conditioned by the tariff rate. The tariff rate is measured as the average over the period in question, while GDP per capita is measured in the initial year of the period. The two world wars are ignored, and the postwar period is studied beginning in 1970 to conform roughly to the era studied by Sachs and Warner (1995). 
The World War II regime switch and the Tariff-Growth Paradox are both quite clear in columns (1) and (6) of Table 1. ${ }^{9}$ Figures 4 and 5 provide the corresponding partial residual scatterplots, with tariffs on the $\mathrm{x}$-axes and growth conditional on a given level of initial income on the y-axes. Naturally, any regression that omits all other variables relevant to growth cannot be regarded as definitive, but it may still be a useful starting point. The estimated coefficient on the tariff rate in the postwar period is -0.0796 and significant; thus, tariffs were associated with slow growth after 1970. In contrast, the estimated coefficient is +0.0307 for $1870-1913$ and significant; tariffs were associated with fast growth before World War I.

\section{The Pre-World War II Tariff-Growth Correlation in More Detail}

Table 2 uses a simple convergence model to explore regional heterogeneity in overall growth performance and in the contribution of tariff policy to it. Observations of annual tariff levels are averaged into non-overlapping periods of five years, and growth on the left hand side now represents growth during each five-year period. Countries are divided into four mutually exclusive, collectively exhaustive clubs as outlined above. The Rich European Offshoots are arbitrarily chosen as the 'base' group, in that for econometric reasons no dummy nor interaction term for this group can be included in the regressions.

Thus the constant term can be thought of as the sum of an estimated constant common to all groups and an estimated dummy for the Rich Offshoots. The "own tariffs" coefficient estimate can be considered the sum of an own-tariff relationship common to all groups and that specific to the Rich Offshoots.

\footnotetext{
${ }^{9}$ Here and elsewhere, curved parentheses show t-statistics while square brackets show standardized beta coefficients. The standardized coefficient reflects the value the coefficient would take if, before running the regression, all variables were normalized to a mean of zero and a standard deviation of unity. Standardized coefficients allow comparison of the relative magnitudes of coefficients in different units, in terms of the change in the regressand with which a change in a given regressor is typically associated. A standardized coefficient of one means that a one standard-deviation change in that regressor is associated with a one-standard deviation change in the regressand.
} 
The estimated own tariff-growth correlation repeats the world-wide finding in Table 1 that high tariffs were associated with good growth before World War I. The coefficient on the own tariff in Table 2 for 1873-1912 (column 1) is +0.0681 and significant. There is, however, clear asymmetry between the regions. Tariffs were associated with much faster growth in the Rich European Offshoots than in the European Periphery or the LDCs, a difference that is statistically significant as well. Tariffs were also associated with somewhat faster growth in the Rich European Offshoots compared with the Core, though the difference is not statistically significant. Note that tariffs actually had a negative association with growth in the European Periphery $(0.0681-0.0828=-0.0147)$ before the War, the standard late $20^{\text {th }}$ century result, but it is the only region for which that finding holds before World War I. During the Interwar years, both the unconditional tariff-growth relationship and the regional asymmetry seen before 1914 appears to break down.

Table 3 is in two parts, and it asks whether the Tariff-Growth Paradox and the regional asymmetry effects disappear when we control for trading partners' growth performance, for the industrial sophistication of the country imposing the tariffs, or for trading partners' tariff policies. ${ }^{10}$ Because data coverage is imperfect for all of these variables, their inclusion restricts the sample size. For this reason, each column including one of these new explanatory variables is preceded by a column that omits it but restricts the sample to exactly the same observations. Comparing coefficients in each of these sets of paired columns, then, allows us to isolate the effect of including the new regressor from the effect of sample restriction.

We begin by pointing out that the Tariff-Growth Paradox is not affected by the inclusion of any of the three regressors - though it is affected by the greatly restricted sample size required to include the

\footnotetext{
${ }^{10}$ Vamvakidis (2002) included in his growth-tariff regressions a "world tariff level" variable calculated as the average tariff in the US, UK, Japan, and Germany. While similar in spirit, our trading partner tariff variable is much richer than this: it is calculated as the average tariff among the trading partners of each individual country, weighted by the exports in each year from the country in question to each partner. This measures quite accurately the tariff
} 
partner growth variable. We see no evidence that the positive correlation between own tariffs and growth is created by the bias of omitting one of these three variables. Table 3 also replicates the regional asymmetry of the tariff relationship we found in Table 2: namely, a positive correlation for the Core, an even bigger positive correlation for the Rich European Offshoots, a much smaller correlation in the LDCs, and a negative correlation in the European Periphery.

Now, does the Paradox or the regional asymmetry evaporate when we control for policy and growth conditions in each country's export market? Column 2 of Table 3a adds the GDP growth performance of principal trading partners (1873-1912). ${ }^{11}$ Booming foreign markets did not have a significant effect before World War I, either in terms of the t-statistic or in terms of the standardized beta coefficient. We found this result surprising given the stress that W. Arthur Lewis has placed on this “engine of growth" (Lewis 1978: pp. 67-75). His "engine of growth" only emerges in the interwar years (column 2 of Table 3b, for 1918-1937), when it was significant and powerful. Column 6 of Table 3 a adds the influence of tariff levels facing exporters in their main markets abroad and finds them unable to explain regional differences. The industrial sophistication of the protecting country, which column 4 attempts to capture as the fraction of exports based on primary products, likewise explains neither the tariff-growth relationship nor the regional asymmetries.

Table 4 addresses the possibility of an endogeneity bias in Tables 1-3. O'Rourke (2000) discusses a potential mechanism of reverse causation between our tariff regressor and what we take to be the dependent variable, GDP growth. In his narrative, prices go up in booms, eroding the share of import duties in total import values during a period when such duties were collected as specific tariffs. Growth subsequently slows down in the slump following the boom and prices fall, so that low tariffs are

environment faced by a typical export on a country-by-country and year-by-year basis.

${ }^{11}$ Here and everywhere else, growth in the home country (our dependent variable) is measured as growth in per capita GDP. Growth in trading partner countries, however, is measured as growth in aggregate GDP. The former is the most appropriate measure of welfare at home; the latter is the most appropriate measure of changing demand 
associated, spuriously, with poor growth. The regressor CYC is calculated precisely as it is by O'Rourke: it is the difference between actual and trend growth, where the latter is predicted from a simple model in which observed growth is regressed on time and time squared. That is, CYC measures short run deviations from long run growth trends. Controlling for booms and busts in Table 4 does not, however, diminish the positive tariff relationship with growth either before 1914 (Table 4, column 2) or after 1918 (Table 4, column 5). This result counsels against an interpretation of the positive coefficient on own tariffs as being the result of endogeneity bias through the mechanism O'Rourke proposes.

Table 4 goes on to use CYC in a slightly different way to reveal that countries were, indeed, "beggaring their neighbors" during the massive interwar global shutdown—but not before. The sign on the interaction of own tariffs with CYC suggests that although tariffs did not help more during recessions than in booms before 1914 (column 3), they certainly did when the Depression hit (columns 8 and 10), especially during recovery in the 1930s. The interaction term in columns 8 and 10 means that, controlling for the large run-up in trading partner tariffs, countries that had been hit hardest by the War and by the crash grew faster in the mid 1920s and late 1930s with high tariffs than with low tariffs. The "beggar thy neighbor" policy may have exported depression, but it helped get rid of it at home. The beta coefficients imply that a one standard deviation decrease in CYC combined with a one standard deviation increase in tariffs was associated with 0.5 standard deviations better growth performance during the mid to late 1930s.

\section{Possible Explanations}

Why did the tariff-growth correlation change? We discuss eight hypotheses.

Hypothesis 1. Strategic tariff policy. It is well known that bilateral tariff policy can generate a prisoners' dilemma in terms-of-trade effects (e.g. Dixit 1987; Bagwell and Staiger 2000). Figure 6

abroad for the home country's exports. 
presents a stylized example. In the home country, on the left side of the figure, domestic demand $D$ for some good $X$ exceeds domestic supply $S$. Home imports the difference at price $p_{0}$ from the foreign country, on the right side of the figure; foreign supply $S^{*}$ exceeds foreign demand $D^{*}$.

Suppose home imposes some tariff $t$ on the good in question, raising the domestic price to $p_{t}$. Home loses area 1-2-3-4 in net consumers' and producers' surplus, but gains area 2-3-5-6 in government revenue. At low tariff levels and with well-behaved curves, the home welfare benefit of home's tariff (area 5-6-7-8) is first order in the tariff whereas the net welfare loss to home from the tariff (triangles 1-2-7 and 3-4-8) is second order. There must exist some tariff level, the 'optimal tariff,' which increases home's welfare relative to free trade.

But the tariff, of course, imposes costs on the foreign country: area $a-b-c-d$, to be precise. But note that area $a-b-c-d=$ area 1-4-5-9 > area 5-6-7-8. The global welfare loss due to any tariff therefore strictly exceeds the private gain to the home country. Both countries would be better off if there were no tariff and foreign paid some fraction of area $a-b-c-d$ to home.

Whence the prisoners' dilemma? Suppose now we consider the market for a different good, $Y$, exported by the home country and imported by the foreign country. A representation of the $Y$ market would be identical to Figure 6 in all respects except that the home country would be represented by the right-hand side of the figure and the foreign country by the left-hand side. By the above reasoning, the foreign country can — by placing some level of tariff on good $Y$-improve its own welfare while decreasing the home country's welfare by some greater amount.

In the absence of policy coordination, the two countries face a prisoners' dilemma as each chooses between free trade and the 'optimal tariff.' Regardless of which strategy is chosen by the foreign country, the home country is better off choosing the 'optimal tariff.' The same is true for the foreign country. Yet both would be better off in the absence of all tariffs. Decisions that are privately unconditionally optimal lead to a collectively suboptimal outcome - the definition of the prisoners' dilemma. 
The possibility of multiple equilibria arises immediately as the game is repeated. In a universe where no tariff policy coordination is possible, all countries raise tariffs to the privately optimal level; those that do not are worse off. In a universe where tariff policy coordination is possible but not universal, country dyads that coordinate are mutually better off for having done so and dyads that do not are worse off. An observer of any country in this universe would note that its welfare improved as it raised tariffs from zero to the privately optimal level.

Now suppose coordination is possible but not universal. There are three countries $A, B$, and $C$, which all trade with each other. Countries $A$ and $B$ are large whereas $C$ is small, and the flow of trade between $A$ and $B$ is absolutely larger than $A$ 's or $B$ 's trade with $C$. Countries $A$ and $B$ coordinate with each other to set zero tariffs. Country $C$ does not coordinate with the other two and sets the 'optimal tariff' against both, prompting $A$ and $B$ to do the same against $C$. What correlation do we observe between tariffs and welfare? Countries $A$ and $B$ collect some small revenue from tariffs on their respective trade with $C$, but collect no revenue on their larger, free trade with each other. Coordination has given them low tariffs and high economic performance. In country $C$ we observe high tariffs and low economic performance.

A change in the observed correlation between tariffs and economic performance, then, could occur as the observer moved from the former universe to the latter. In a pre-1914 world where a few, large, important countries forewent coordination in favor of high tariff barriers, our simple model predicts that tariffs would be positively associated with economic performance in all countries. In a post-1950 world where a few, large, important countries embraced coordination in favor of mutually lowering tariffs, we expect a negative association between tariffs and performance-again, in all countries.

While we favor Hypothesis 1, there is no shortage of plausible alternative explanations for an identical observed shift in the correlation between tariffs and economic performance from positive before 1914 to negative after 1950 . These alternative hypotheses include:

Hypothesis 2. Changing patterns of economic performance among trading partners. Looking 
again at Figure 6, it is clear that shifts in the various curves could generate corresponding changes in the relationship between tariff policy and welfare. Increased productivity growth and competitiveness in the foreign exporter, for example, could alter the $S^{*}$ curve and thereby the $S+\left(S^{*}-D^{*}\right)$ curve. Respectively, growth would shift it outward and decreased market power would flatten it. Both of these would tend to increase the ratio of distortion costs to terms-of-trade benefits of the tariff in the home country. If a few large, important trading countries were experiencing better economic growth in the post-1950 period than before it, then, we might imagine conditions under which the correlation between own tariffs and own economic performance would undergo a corresponding change from negative to positive.

Hypothesis 3. Changes in transportation costs. Figure 6 implicitly assumes, of course, zero transportation costs between exporter and importer. Introducing such costs would place a wedge between domestic price and $p^{*}$ in a manner identical to that of tariff barriers. Augmenting this wedge by placing tariff barriers on top of large pre-existing transportation cost barriers would have a lesser proportional effect on the areas of the respective triangles and rectangles, the larger are the transportation costs relative to the tariffs. Such a story requires the implicit assumption that, as in Figure 6, supply and demand are convex. We can thus readily imagine a world of high transportation costs— the pre-1914 world of steam ships with no Panama Canal—where geographic barriers prevent coordination around a truly free-trade equilibrium. In such a world, with prices already severely distorted by the tyranny of distance, the costs of tariffs would seem less noticeable while the benefits of tariff revenue would be as noticeable as ever. 'Obligatory tariffs' in the form of international transportation costs continued their decline after 1900, placing into countries' hands for the first time the power to largely determine the size of the wedge between domestic and international prices. This opened up the possibility for negotiated high-level equilibria of free trade, and for the first time low tariffs appeared to be associated with noticeably better performance.

Hypothesis 4. Changes in the type of goods targeted by tariffs. It is also possible that, rather 
than shifting supply and demand for good $X$ in Figure 6 changing the relative costs and benefits of the tariff, instead tariffs came to be applied to some other good $Z$ characterized by differently-shaped supply and demand and thus different tariff-related benefits and costs. Imagine, for example, that before 1914 the home country was placing tariffs on some agricultural good $X$ whose supply and demand curves were such that the home benefits of the tariff exceeded its costs. After 1950, imagine that home shifted its tariffs to some manufactured good $Z$ for which the costs of large tariff barriers exceeded the benefits. If the foreign country were to follow suit, for the same (exogenous) reason, then we might observe an across-the-board negative correlation between tariffs and economic performance after 1950 unrelated to any game being played between home and foreign.

Hypothesis 5. Changes in industrialization. In the Hypothesis 4 preceding, the level of industrialization of the home country did not change; home merely shifted its tariffs from non-industrial to industrial goods. Suppose instead that home did not change its tariff schedule at all but rather home's and foreign's economies became more industrialized. This would shift the demand and supply curves for a given industrial or non-industrial good represented by Figure 6, and thereby also shift the relative costs and benefits of tariffs on-say - a given industrial good. All of the major trading nations on earth underwent such structural change between the late $19^{\text {th }}$ century and the late $20^{\text {th }}$, and perhaps this could explain the changing relationship between tariffs and performance.

Hypothesis 6. Changes in the instruments of trade policy. Suppose that tariffs always bring a net benefit to the home country, but the primary instrument of trade policy shifted (exogenously) from tariffs before 1914 to non-tariff barriers after 1950. In this case we might still observe a positive correlation between tariffs and performance before 1914. After 1950 we might see neither a positive nor a negative relationship, or if tariffs happened to be correlated with other "bad policies" we might observe a spuriously negative relationship.

\section{Hypothesis 7. Changes in other policies or conditions affecting growth that happen to be}


correlated with tariff policy. Suppose that no game is being played between home and foreign. Rather, suppose there is some basket of policies or conditions that hurt economic performance and that were adopted after 1950 by the same countries—for exogenous reasons—-that retained high tariff barriers. Tariffs continued to augment performance as they had before 1914, but this light could not be discerned through the fog of the concurrent growth-impeding processes in high-tariff countries. A hypothetical example is a case in which now-rich countries developing before 1914 used tariffs to ride high while colonies were forced by their masters' management to have neither growth nor tariffs. In the late $20^{\text {th }}$ century these colonies became independent and used their newfound freedom to impose high tariffs as their masters had earlier-while growing slowly due to some aspect of the colonial legacy rather than due to high tariffs. In this case we would observe a "true" positive correlation between economic performance and tariffs before 1914 and a spuriously negative correlation later.

Another instrument for placing a wedge between real domestic and foreign prices is exchange rate policy. Prior to 1914, exchange rates were frequently fixed by participation in the Gold Standard, while after the 1970s many important currencies floated more or less freely. Perhaps tariff distortions to relative prices were compensated for by countervailing exchange rate movements in the late $20^{\text {th }}$ century, clouding the observability of their positive impact on performance.

Hypothesis 8. Changes in non-tariff taxation. Lastly, suppose states relied to a greater relative degree on tariffs for their revenue before 1914 than they did in the late $20^{\text {th }}$ century. In that case a hightariff state before 1914 may have been a state with highly distorted prices, but it was also a state with sufficient revenue to govern well and ensure the stability and predictability necessary for growth. After 1950, as national governments developed broader and less distorting sources of revenue, the story would go, states with high tariffs were no longer necessarily those with well-funded governments but they were still states with highly distorted prices and consequently poor economic performance. We would still observe a positive correlation between tariffs and growth before the wars, diminishing or even reversing 
thereafter.

\section{Testing Competing Hypotheses}

To test the first three hypotheses we require quantitative measures of tariff levels, GDP growth, and transportation costs for each country's trading partners. Indices for each of these three characteristics were constructed as weighted averages for the top 5 trading partners of the country in question (before 1914) or for all trading partners of the country (after 1950), where the weights are the value of trade going from the country in question to each partner in a given period. For example, our index of trading partner tariffs for Indonesia in 1975 is the average tariff of all countries in the database, weighted by the total exports going from Indonesia to each country in that year. Growth in trading partners was measured as GDP growth rather than GDP per capita growth, since only the total export market size is relevant to a trading partner's welfare. Effective distance is defined as the product of an international transportation cost index ${ }^{12}$ and the physical distance between the principal cities of commerce in each country pair.

We also require a measure of economic performance at home, which we take to be real growth in GDP per capita, and an identification strategy. The simple model of Figure 6 predicts that tariffs should affect levels of welfare, not growth, but says nothing about how long such effects should take. Certainly taking growth as the measure of economic performance requires implicit assumptions about the dynamic effects of tariff policy on welfare, but the same is true of any such measure. If the empirical literature on economic growth has convinced us of nothing else it should be that economic welfare is in transition in most countries - thus the frequent significance of initial income in growth regressions. We have no theoretical reason to believe that the predicted tariff impact on welfare would be completely realized within

\footnotetext{
${ }^{12}$ See data appendix for details on index construction.
} 
any particular time period or would only begin to do so-in which case its impact could just as easily be observed as a transitional impact on growth. If changing tariffs alter the steady state then they can and in fact must change the rate at which that steady state is approached, quite independently of fixed effects. Looking beyond our simple model, we also note that to the extent that tariffs alter the cost of capital goods or research and development—and therefore of investment and capital accumulation—tariffs could alter the rate of growth in a manner totally independent of their effects on the steady state (Grossman and Helpman 1991; Easterly 1993; Osang and Pereira 1996; Ben-David and Loewy 1998; Baldwin and Forslid 2000). Tariffs also can, but do not necessarily, change domestic economic structure in a way that promotes or impedes growth (Irwin 2002) and might influence growth by influencing access to international credit (Lane 2001). But these points overstep the scope of the present work; suffice it to say that we find ample justification for using growth as a measure of welfare impact.

Our identification strategy requires the assumption that our measure of tariff policy is exogenous with respect to growth. Without doubt, there are other predictions of the simple model in Figure 6 that could be empirically tested; the most obvious is that welfare changes should occur hand-in-hand with growth in volume of trade. While it might be of interest to include trade growth as a check on the mechanism of the relationship we seek, no plausible argument could be made for its exogeneity. We are faced with a research strategy choice between investigating the relationship between our variables of interest—-tariffs and growth—directly, and introducing more subtle and less intuitive estimators. We employ Occam's razor in this paper and elect the former strategy. However, we will perform robustness checks on the exogeneity of our tariff measure along the way.

Lastly, we require the assumption that our calculated tariff rate, import duties over the value of total imports, measures the degree to which goods prices are distorted by the tariff. As noted by O'Rourke (1997; 2000), there need not be any relationship between collected tariffs and distortion; consider the extreme example of a one thousand percent tariff that suppresses trade entirely, resulting in zero collected 
tariff revenues. While Pritchett and Sethi (1994) find only a weak empirical relationship between collected and statutory tariff rates, their estimated relationship only breaks down at tariff rates above $50 \%$, a level far higher than the average tariff rate which history documents over the past century and a half. In any case, the existence of a tariff-induced terms-of-trade effect as illustrated by Figure 1 rests on the assumption that agents $d o$ alter their behavior, and that statutory and collected tariffs do not move in lockstep.

Turning now to the results, we see that Hypothesis 2 is not supported by column (8) of Table 1. The interaction term between own tariffs and trading partner growth is positive and significant. Perhaps this is because when trading partners are growing briskly and exports to those partners are doing well, countries can "afford" the costs of tariffs. But the sign on the interaction term makes it clear that an environment of lower trading partner growth such as prevailed before 1914 would decrease rather than increase the correlation between own tariffs and growth. Thus, it cannot account for the Paradox.

Hypothesis 3 is not supported by column (9) of Table 1. There is no statistically significant relationship between average trading partner distance and the tariff-growth correlation during the 19701998 period. Thus, it too cannot account for the Paradox.

Hypothesis 1, however, deserves a closer look. The sign on the interaction term between own tariff levels and weighted average partner tariffs is positive and significant in column (7). This positive sign means that although high tariffs and low growth tend to be found together following 1970, it is nevertheless true that within that group, the highest tariffs are found with the highest growth when partner tariffs are highest. If the same relationship were to persist as partner tariffs grew to levels sufficiently higher than those seen during 1970-1998, we might expect the unconditional negative relationship between own tariffs and growth to change sign.

Figures 7, 8, and 9 display the partial residual scatterplots for own tariffs, partner tariffs, and the interaction term—respectively—from column (7) of Table 1. In each figure, the x-axis shows the regressor 
in question while the y-axis shows conditional growth, holding constant all other regressors. The positive sign on the interaction term in Figure 9 is strong and is produced neither by outlier countries nor regions.

It remains, then, to inquire whether or not the change in the world tariff environment observed between the late $19^{\text {th }}$ century and the late $20^{\text {th }}$ was sufficiently large to produce a sign change in the unconditional tariff-growth relationship. Table 5 takes simple averages across all sample countries for the two periods, showing that the average trading partner tariff rate fell by more than a third, $-4.27 \%$ in terms of import duties over imports, while average trading partner growth rose by a third, $+1.18 \%$ in terms of annual GDP growth. We have seen that, given the positive sign on the interaction between own tariffs and partner growth, a rise in partner growth could not have produced a negative flip in the relationship between own tariffs and growth. But if average partner tariffs were to gain back the four percent they lost between the late $19^{\text {th }}$ and the late $20^{\text {th }}$ centuries, would the coefficients from the late $20^{\text {th }}$ century once again yield a positive unconditional relationship between own tariffs and growth?

Figure 10 explores this question. The figure is the two-dimensional representation of a threedimensional surface, where contours represent height measured against a z-axis emerging from the flat surface of the page. The $\mathrm{x}$-axis shows a simulated increase in own tariff levels starting from their average 1970-1998 values, measured in percent (import duties over imports). The y-axis shows a similar simulated change in partner tariff levels. The z-axis reflects the change in GDP per capita growth measured as percent per year corresponding to the tariff changes, based on the coefficients estimated in column (7) of Table 1. Each contour line reflects a change in growth of $0.2 \%$ per year. Those contours lying below zero are in white, while those lying above zero are in gray. Figure 10 is simply a graphical representation of the equation estimated in column (7) of Table 1.

To use this contour plot, begin at the bottom left hand corner. Here, own tariff levels and partner tariff levels are at the average value observed for 1970-1998 given in Table 5. Thus the deviation from 
average is zero at the origin. Likewise, own growth is at its average 1970-1998 rate as given in Table 5, so the simulated deviation from average growth is zero and the height of the contours is zero.

If one were to increase own tariffs without changing anything else in the simulation, equivalent to a horizontal slide rightward from the origin, the associated change in growth would be negative. From the figure, an increase of roughly $3.5 \%$ in own tariffs would be associated with a $0.2 \%$ fall in GDP per capita growth. This is expected, and is equivalent to the result from column (6) of Table 1 that, unconditionally, increases in tariffs were associated with diminished growth after 1970. Note also that a movement vertically upward from the origin, corresponding to a simulated rise in trading partner tariffs without any increase in own tariffs, likewise stifles growth.

The positive interaction term from column (7) of Table 1 means, however, that a rise in own tariffs associated with a rise in trading partner tariffs might be positively related to growth. This is seen in the fact that, for example, a four percent rise in own tariffs could actually be beneficial for growth if adopted in response to a four percent rise in trading partner tariffs—relative to what would happen to growth if trading partners raised their tariffs and there were no response at home. Figure 10 may seem a counterintuitive representation of the prisoners' dilemma, since mutual "defection" appears to be beneficial. But the payoffs in Figure 10 are private and conditional; to say that the home country is better off defecting given that the foreign country has done so is quite different from saying that mutual defection brings mutual benefit.

Figure 10 merely expresses correlations observed after 1970 and does not suggest a mechanism by which hypothetical changes in the world tariff environment could change the relationship between own tariffs and growth. The estimated model is in partial equilibrium and we cannot know if the linear relationships estimated in Table 1 would hold true if tariffs were in fact to change. But the simulation is very suggestive. Average trading partner tariffs fell by around four percent between the late $19^{\text {th }}$ century and the late $20^{\text {th }}$, and if we simulate a return to the $19^{\text {th }}$ century by raising partner tariffs back up by four 
percent—within the late $20^{\text {th }}$ century equation—we get back the $19^{\text {th }}$ century positive unconditional tariffgrowth relationship. Not only does the interaction term in column (7) of Table 1 have the correct sign for a change in the world tariff environment to have been responsible for flipping the tariff-growth relationship, but the estimated coefficient also has just the right magnitude.

\section{Discussion}

We do not claim to have shown a relationship between economic growth and overall "openness" or "outward orientation." The various measures of openness commonly used are more often than not pairwise uncorrelated (Pritchett 1996) and amalgamated measures of openness suffer from collinearity with non-trade policies affecting growth (Rodríguez and Rodrik 2001). We seek only to investigate the possible effects of tariff levels, and to the extent that higher tariffs imply a protectionist stance, we can make statements on one aspect of protectionism. But our tariff variable should not be viewed as an overall measure of how "protected" an economy is.

In section 5 we proposed eight hypotheses for why the tariff-growth correlation might have changed between the late 19th century and the late 20th. In section 6 we sought to address the first three. We found that the statistical and economic significance of the data support Hypothesis 1 - that a shift from one equilibrium of a repeated prisoners' dilemma might have occurred—but not Hypotheses 2 and 3 involving changing patterns of trading partner growth and transportation costs. But we have not yet addressed the remaining five alternative explanations.

Hypothesis 5, suggesting that the correlation between tariffs and growth is sensitive to level of industrialization, finds no support in Table 3a. Controlling for the fraction of exports based on primary products before 1914 does not in the slightest affect the observed positive correlation between tariffs and growth. Restricting the post-1970 sample in column 6 of Table 1 to the less-industrialized countries, for 
example those with GDP per capita less than US\$4,000, does not materially alter the magnitude or the statistical significance of the coefficient on own tariffs.

We do not have the data at hand to test directly Hypothesis 4, that changes in the types of goods to which tariffs were applied were responsible for the changing relationship between tariffs and economic performance. A centralized database of international pre-1914 tariffs broken down by does not yet exist. Nor do we have reliable quantitative indicators of a century of non-tariff barriers, the effects of "colonial legacy,' and pre-1914 government revenue structure that would allow us to test directly Hypotheses 6, 7, and 8. We do note, however, that any indicator of 'colonial legacy' or of consistently bad policy would be constructible as a linear combination of the country fixed effects included in Table 4, which do not diminish the significance of the own tariff coefficient. We interpret this as casting doubt on Hypothesis 7 , that changes in country-specific conditions or can explain away the changing tariff-growth relationship. In some future project, it might be possible to collect exact quantitative measures since 1870 of the covarying policies thought to affect the tariff-growth relationship. But in the absence of such evidence, tests of these additional hypotheses will have to await further research.

\section{Condusion}

Given the data we have been able to scratch out of the archives so far, the best explanation for the Tariff-Growth Paradox is the fact that since W orld W ar II, tariff barriers faced by the average exporting country have fallen to their lowest levels in a century and a half. A fter accounting for this change, there is no incompatibility between the less well-known positive tariff-growth correlation before 1914 and the very well-known negative tariff-growth correlation since 1970. Other potential explanations we test quantitatively cannot compete. A simple calculation can, by simulating a return to 
pre-1914 levels of tariffs worldwide, recreate the exact magnitude of the pre-1914 positive correlation between tariffs and growth using post-1970 data.

In a larger sense, our findings suggest that it has not always been true that countries with high tariffs finish last, and it need not be true in the future either. There is growing evidence suggesting that the benefits of openness, one of the cornerstones of the Washington Consensus and the GATT/WTO negotiations, are neither inherent nor irreversible but rather depend upon the state of the world. In a very real sense, heads of state considering the move to openness are facing a game, rather than an isolated decision.

In such a world, the low-level equilibrium of mutually high tariffs is only as far away as some big world event that persuades influential leader-countries to switch to anti-global policies. F eedback ensures that the rest must follow in order to survive. As well, the high-level equilibrium of low tariffs we now enjoy was only as far away as the nascent OECD coordination of the early postwar years, and the creation of trans-national public institutions whose express purpose was to impede the return to interwar autarky.

This does not mean that it would be advisable for follower countries to reverse the process of liberalization in the face of a potential return to protectionism in leader countries. It is the nature of the repeated prisoners' dilemma that playing the "defect" strategy never leads to the best outcome, even if in a single round of the game it is privately unconditionally optimal. M utual cooperation is the best outcome, and a cooperative equilibrium is destroyed by a defection. Our results suggest that "defection" by leader countries in the form of higher tariffs may lead inevitably to higher tariffs in the followers, but this is fundamentally distinct from any suggestion that it is somehow in the followers' best interests to do so. At the end of the day, only cooperation is in the best interests of the "prisoners." 
But what sparks such shifts from one equilibrium to another? Who leads and who follows? Why did it happen in the 1920s and 1950s-and could it happen again? We look forward to future research on endogenous tariffs to explain the dynamics of these important policy changes. 


\section{References}

Anderson, James E. 1998. “Trade Restrictiveness Benchmarks.” Economic Journal 108 (July): 1111-25.

Anderson, James E. and J. Peter Neary. 1994. "Measuring the Restrictiveness of Trade Policy.” World Bank Economic Review 8 (May): 151-69.

Bagwell, Kyle and Robert W. Staiger. 2000. “GATT-Think.” NBER Working Paper 8005, National Bureau of Economic Research, Cambridge, Mass.

Bairoch, Paul. 1972. "Free Trade and European Economic Development in the $19^{\text {th }}$ Century." European Economic Review 3 (November): 211-45.

Baldwin, Richard E. and Rikard Forslid. 2000. "Trade liberalisation and endogenous growth: A $q$-theory approach.” Journal of International Economics 50: 497-517.

Ben-David, Dan and Michael B. Loewy. 1998. "Free Trade, Growth, and Convergence.” Journal of Economic Growth 3: 143-170.

Bhagwati, Jagdish and Anne O. Krueger (eds.). 1973-1976. Foreign Trade Regimes and Economic Development, multiple volumes with varying authorship. New York: Columbia University Press.

Blattman, Chris, Michael A. Clemens and Jeffrey G. Williamson. 2002. "Who Protected and Why? Tariffs the World Around 1870-1937." Paper presented to the Conference on the Political Economy of Globalization, Trinity College, Dublin (August 29-31).

Bloom, David E. and Jeffrey G. Williamson. 1998. "Demographic Transitions and Economic Miracles in Emerging Asia.” World Bank Economic Review 12 (September): 419-55.

Capie, Forrest. 1983. "Tariff Protection and Economic Performance in the Nineteenth Century.” In J. Black and L. A. Winters (eds.), Policy and Performance in International Trade. London: Macmillan.

Coatsworth, John H. and Jeffrey G. Williamson. 2002. "The Roots of Latin American Protectionism: 
Looking Before the Great Depression.” NBER Working Paper 8999, National Bureau of Economic Research, Cambridge, Mass. (June).

Dixit, Avinash. 1987. "Strategic Aspects of Trade Policy.” In Truman F. Bewley (ed.), Advances in Economic Theory: Fifth World Congress. New York: Cambridge University Press.

Dollar, David. 1992. “Outward-Oriented Developing Economies Really Do Grow More Rapidly: Evidence from 95 LDCs, 1976-1985.” Economic Development and Cultural Change 40 (April): 523-44.

Dollar, David and Aart Kraay. 2000. “Trade, Growth, and Poverty.” World Bank Policy Research Department Working Paper No. 2615. Washington, DC (March).

Easterly, William. 1993. "How much do distortions affect growth?” Journal of Monetary Economics 32 (2): $187-212$.

Eckes, Alfred, 1995. Opening America's Market: U.S. Foreign Trade since 1776. Chapel Hill: University of North Carolina Press.

Edwards, Sebastian. 1993. "Openness, Trade Liberalization, and Growth in Developing Countries.” Journal of Economic Literature 31 (September): 1358-94.

Frankel, Jeffrey and David Romer. 1999. “Does Trade Cause Growth?” American Economic Review 89 (June): 379-99.

Greenaway, David, Wyn Morgan, and Peter Wright. 2002. "Trade liberalisation and growth in developing countries." Journal of Development Economics 67: 229-44.

Grossman, Gene M. and Elhanan Helpman. 1991. Innovation and Growth in the Global Economy. Cambridge: The MIT Press.

Harrison, Ann. 1996. “Openness and growth: A time-series, cross-country analysis for developing countries." Journal of Development Economics 48: 419-47.

Irwin, Douglas A. 1998. "Changes in U.S. Tariffs: The Role of Import Prices and Commercial Policies?" American Economic Review 88 (September): 1015-26. 
Irwin, Douglas A. 2001. "Tariffs and Growth in Late Nineteenth Century America," World Economy 24 (January):15-30.

Irwin, Douglas A. 2002. "Did Import Substitution Promote Growth in the Late Nineteenth Century?" NBER Working Paper 8751, National Bureau of Economic Research, Cambridge, Mass. (February).

Irwin, Douglas A. and Marko Terviö. 2002. "Does Trade Raise Income? Evidence from the Twentieth Century.” Journal of International Economics 58(1):1-18.

Krueger, Anne O. 1983. "The Effects of Trade Strategies on Growth.” Finance and Development 20 (June): 6-8.

Krueger, Anne O. 1984. "Trade Policies in Developing Countries.” In Ronald Jones and Peter Kenan (eds.), Handbook of International Economics, volume 1. Amsterdam: North-Holland.

Lane, Philip R. 2001. “International trade and economic convergence: the credit channel.” Oxford Economic Papers 53: 221-40.

Lewis, W. Arthur. 1978. The Evolution of the International Economic Order. Princeton: Princeton University Press.

Lindert, Peter H. and Jeffrey G. Williamson. 2001. "Does Globalization Make the World More Unequal?" NBER Working Paper 8228, National Bureau of Economic Research, Cambridge, Mass. (April).

O’Rourke, Kevin H. 1997. “Measuring Protection: A Cautionary Tale.” Journal of Development Economics 53: 169-83.

O'Rourke, Kevin H. 2000. "Tariffs and Growth in the Late 19th Century.” Economic Journal 110 (April): 456-83.

Osang, Thomas and Alfredo Pereira. 1996. "Import tariffs and growth in a small open economy.” Journal of Public Economics 60: 45-71.

Pritchett, Lant. 1996. “Measuring outward orientation in LDCs: Can it be done?" Journal of 
Development Economics 49: 307-35.

Pritchett, Lant and Geeta Sethi. 1994. "Tariff Rates, Tariff Revenue, and Tariff Reform: Some New Facts." The World Bank Economic Review 8 (1, January):1-16.

Rodríguez, Francisco and Dani Rodrik. 2001. “Trade Policy and Economic Growth: A Skeptic's Guide to the Cross-National Evidence,” in Ben Bernanke and Kenneth S. Rogoff, eds., Macroeconomics Annual 2000, Cambridge, MA: MIT Press for NBER.

Sachs, Jeffrey D. and Andrew Warner. 1995. "Economic Reform and the Process of Global Integration." Brookings Papers on Economic Activity 1: 1-118.

Vamvakidis, Athanasios. 2002. "How Robust Is the Growth-Openness Connection? Historical Evidence." Journal of Economic Growth 7: 57-80.

Williamson, Jeffrey G. 1998. “Globalization, Labor Markets and Policy Backlash in the Past.” Journal of Economic Perspectives 12 (Fall): 51-72.

Wright, Gavin. 1990. “The Origins of American Industrial Success, 1879-1940.” American Economic Review 80 (September): 651-68. 


\section{Table 1. Dependent variable: Annual average growth in GDP/capita during entire period}

OLS regressions, where each observation is one country for the entire period in question

\begin{tabular}{|c|c|c|c|c|c|c|c|c|c|c|}
\hline Regression Number & (1) & (2) & (3) & (4) & (5) & (6) & (7) & (8) & (9) & (10) \\
\hline Time Period & & & $1870-1913$ & & & & & 1970-1998 & & \\
\hline $\begin{array}{l}\text { GDP/capita in } \\
\text { first year of period }\end{array}$ & $\begin{array}{l}2.42 \mathrm{E}-06 \\
(0.02) \\
{[0.00310]}\end{array}$ & $\begin{array}{l}-4.69 \mathrm{E}-05 \\
(-0.35) \\
{[-0.0625]}\end{array}$ & $\begin{array}{l}-5.43 \mathrm{E}-05 \\
(-0.41) \\
{[-0.0724]}\end{array}$ & $\begin{array}{l}-5.36 \mathrm{E}-05 \\
(-0.46) \\
{[-0.0714]}\end{array}$ & $\begin{array}{l}-8.17 \mathrm{E}-05 \\
(-0.68) \\
{[-0.109]}\end{array}$ & $\begin{array}{l}-7.87 \mathrm{E}-06 \\
(-0.16) \\
{[-0.0190]}\end{array}$ & $\begin{array}{l}-7.57 \mathrm{E}-06 \\
(-0.15) \\
{[-0.0195]}\end{array}$ & $\begin{array}{l}3.55 \mathrm{E}-06 \\
(0.07) \\
{[0.00912]}\end{array}$ & $\begin{array}{l}2.88 \mathrm{E}-05 \\
(0.57) \\
{[0.0740]}\end{array}$ & $\begin{array}{l}-2.07 \mathrm{E}-06 \\
(-0.04) \\
{[-0.00532]}\end{array}$ \\
\hline $\begin{array}{l}\text { Period average } \\
\text { own tariff rate }\end{array}$ & $\begin{array}{l}0.0307 \\
(2.46) \\
{[0.411]}\end{array}$ & $\begin{array}{l}0.0402 \\
(1.41) \\
{[0.560]}\end{array}$ & $\begin{array}{l}0.0381 \\
(0.80) \\
{[0.532]}\end{array}$ & $\begin{array}{l}-0.0265 \\
(-1.27) \\
{[-0.369]}\end{array}$ & $\begin{array}{l}-0.0228 \\
(-0.35) \\
{[-0.318]}\end{array}$ & $\begin{array}{l}-0.0796 \\
(-2.71) \\
{[-0.328]}\end{array}$ & $\begin{array}{l}-0.326 \\
(-3.22) \\
{[-1.429]}\end{array}$ & $\begin{array}{c}-1.23 \\
(-2.67) \\
{[-5.41]}\end{array}$ & $\begin{array}{l}0.00211 \\
(0.03) \\
{[0.00925]}\end{array}$ & $\begin{array}{l}-0.839 \\
(-1.64) \\
{[-3.68]}\end{array}$ \\
\hline $\begin{array}{l}\text { Interaction of own } \\
\text { tariff \& partner tariff }\end{array}$ & & $\begin{array}{l}-0.00186 \\
(-0.69) \\
{[-0.447]}\end{array}$ & & & $\begin{array}{l}-0.000983 \\
(-0.20) \\
{[-0.237]}\end{array}$ & & $\begin{array}{l}0.0485 \\
(2.64) \\
{[1.49]}\end{array}$ & & & $\begin{array}{l}0.0309 \\
(1.39) \\
{[0.949]}\end{array}$ \\
\hline $\begin{array}{l}\text { Trading partner } \\
\text { annual GDP growth }\end{array}$ & & & $\begin{array}{l}0.313 \\
(1.11) \\
{[0.344]}\end{array}$ & & $\begin{array}{l}0.0848 \\
(0.19) \\
{[0.0932]}\end{array}$ & & & $\begin{array}{l}-5.39 \\
(-2.51) \\
{[-0.511]}\end{array}$ & & $\begin{array}{l}-3.33 \\
(-1.29) \\
{[-0.315]}\end{array}$ \\
\hline $\begin{array}{l}\text { Average effective distance } \\
\text { to trading partners }\end{array}$ & & & & $\begin{array}{l}-0.000280 \\
(-2.30) \\
{[-0.833]}\end{array}$ & $\begin{array}{l}-0.000293 \\
(-2.31) \\
{[-0.871]}\end{array}$ & & & & $\begin{array}{l}0.000106 \\
(0.44) \\
{[0.0891]}\end{array}$ & $\begin{array}{l}0.000194 \\
(0.79 \\
{[0.164]}\end{array}$ \\
\hline $\begin{array}{l}\text { Interaction of own tariff } \\
\& \text { partner effective distance }\end{array}$ & & & & $\begin{array}{l}2.08 \mathrm{E}-05 \\
(3.01) \\
{[1.37]}\end{array}$ & $\begin{array}{l}2.26 \mathrm{E}-05 \\
(3.15) \\
{[1.50]}\end{array}$ & & & & $\begin{array}{l}-1.97 \mathrm{E}-05 \\
(-1.08) \\
{[-0.381]}\end{array}$ & $\begin{array}{l}-2.08 \mathrm{E}-05 \\
(-1.11) \\
{[-0.403]}\end{array}$ \\
\hline Constant & $\begin{array}{c}0.836 \\
(3.25)\end{array}$ & $\begin{array}{r}0.500 \\
(1.00)\end{array}$ & $\begin{array}{r}0.357 \\
(0.57)\end{array}$ & $\begin{array}{c}1.68 \\
(4.57)\end{array}$ & $\begin{array}{c}1.17 \\
(1.66)\end{array}$ & $\begin{array}{c}2.39 \\
(4.14)\end{array}$ & $\begin{array}{c}5.96 \\
(3.64)\end{array}$ & $\begin{array}{l}20.9 \\
(2.75)\end{array}$ & $\begin{array}{c}1.59 \\
(1.59)\end{array}$ & $\begin{array}{l}15.7 \\
(1.90)\end{array}$ \\
\hline $\mathrm{N}$ & 33 & 32 & 32 & 32 & 32 & 97 & 91 & 91 & 91 & 91 \\
\hline $\mathrm{R}-\mathrm{Sq}$ & 0.170 & 0.197 & 0.206 & 0.380 & 0.474 & 0.100 & 0.179 & 0.177 & 0.133 & 0.210 \\
\hline Adj R-Sq & 0.114 & 0.0784 & 0.0884 & 0.288 & 0.291 & 0.0810 & 0.141 & 0.138 & 0.0920 & 0.133 \\
\hline
\end{tabular}

t-statistics (White standard errors) are in parentheses immediately below each coefficient estimate. Standardized beta coefficients are in square brackets. 
Table 2. Dependent variable: Annual average growth in GDP/capita during periods of five years

OLS regressions, where each observation is the average value of the regressor in one country during a period of five years

\begin{tabular}{|c|c|c|}
\hline Time Period & $\begin{array}{c}1873- \\
1912\end{array}$ & $\begin{array}{c}1918- \\
1937\end{array}$ \\
\hline $\begin{array}{l}\text { Period-initial } \\
\text { GDP per capita }\end{array}$ & $\begin{array}{l}-0.0000827 \\
(-0.64)\end{array}$ & $\begin{array}{l}-0.000890 \\
(-2.87)\end{array}$ \\
\hline Own tariff & $\begin{array}{l}0.0681 \\
(2.33)\end{array}$ & $\begin{array}{l}-0.0461 \\
(-0.54)\end{array}$ \\
\hline $\begin{array}{l}\text { (Core dummy) } \times(\text { Own } \\
\text { tariff })\end{array}$ & $\begin{array}{l}-0.0448 \\
(-1.13)\end{array}$ & $\begin{array}{l}0.0845 \\
(0.59)\end{array}$ \\
\hline $\begin{array}{l}\text { (European Periphery } \\
(\text { dummy }) \times(\text { Own tariff })\end{array}$ & $\begin{array}{l}-0.0828 \\
(-2.51)\end{array}$ & $\begin{array}{l}-0.0961 \\
(-0.91)\end{array}$ \\
\hline $\begin{array}{l}(\text { LDC dummy }) \times \\
(\text { Own tariff })\end{array}$ & $\begin{array}{l}-0.0627 \\
(-2.03)\end{array}$ & $\begin{array}{l}0.0729 \\
(0.78)\end{array}$ \\
\hline Core dummy & $\begin{array}{c}1.05 \\
(1.38)\end{array}$ & $\begin{array}{c}0.480 \\
(0.20)\end{array}$ \\
\hline $\begin{array}{l}\text { European Periphery } \\
\text { dummy }\end{array}$ & $\begin{array}{c}1.05 \\
(1.34)\end{array}$ & $\begin{array}{l}0.718 \\
(0.35)\end{array}$ \\
\hline LDC dummy & $\begin{array}{c}0.504 \\
(0.61)\end{array}$ & $\begin{array}{l}-3.38 \\
(-1.52)\end{array}$ \\
\hline Constant & $\begin{array}{c}0.386 \\
(0.45)\end{array}$ & $\begin{array}{c}5.00 \\
(2.16)\end{array}$ \\
\hline $\begin{array}{l}\mathrm{N} \\
\mathrm{R} \text {-squared }\end{array}$ & $\begin{array}{l}274 \\
0.0840\end{array}$ & $\begin{array}{r}132 \\
0.0994\end{array}$ \\
\hline
\end{tabular}

t-statistics are in parentheses immediately below each coefficient estimate. 
Table 3a: Can We Explain Regional Differences in Tariff Effects (1873-1912)?

\section{Dependent variable: Annual average growth in GDP/capita during period of five years}

OLS regressions, where each observation is the average value of the regressor in one country during a period of five years

Time Period

Period-initial

GDP per capita

Own tariff

European Periphery

(dummy) $\times($ Own tariff $)$

(Core dummy) $\times$

(Own tariff)

(LDC dummy) $\times$

(Own tariff)

European Periphery

dummy

Core dummy

LDC dummy

Average GDP growth

among trading partners

Fraction of exports based

on primary products

Tariff index for principal

trading partners

Constant

$\mathrm{N}$

R-squared

Adjusted R-squared

1873-1912

\begin{tabular}{|c|c|c|c|c|c|}
\hline $\begin{array}{l}-0.000103 \\
(-0.71) \\
{[-0.0856]}\end{array}$ & $\begin{array}{l}-8.77 \mathrm{E}-05 \\
(-0.60) \\
{[-0.0726]}\end{array}$ & $\begin{array}{l}-8.27 \mathrm{E}-05 \\
(-0.64) \\
{[-0.0674]}\end{array}$ & $\begin{array}{l}-8.47 \mathrm{E}-05 \\
(-0.66) \\
{[-0.0689]}\end{array}$ & $\begin{array}{l}-0.000106 \\
(-0.77) \\
{[-0.0830]}\end{array}$ & $\begin{array}{l}-0.000112 \\
(-0.80) \\
{[-0.0883]}\end{array}$ \\
\hline $\begin{array}{l}0.0241 \\
(0.69) \\
{[0.184]}\end{array}$ & $\begin{array}{l}0.0184 \\
(0.52) \\
{[0.141]}\end{array}$ & $\begin{array}{l}0.0681 \\
(2.33) \\
{[0.563]}\end{array}$ & $\begin{array}{l}0.0693 \\
(2.37) \\
{[0.574]}\end{array}$ & $\begin{array}{l}0.0757 \\
(2.30) \\
{[0.593]}\end{array}$ & $\begin{array}{l}0.0777 \\
(2.30) \\
{[0.609]}\end{array}$ \\
\hline $\begin{array}{l}-0.0426 \\
(-1.11) \\
{[-0.293]}\end{array}$ & $\begin{array}{l}-0.0355 \\
(-0.91) \\
{[-0.244]}\end{array}$ & $\begin{array}{l}-0.0828 \\
(-2.51) \\
{[-0.517]}\end{array}$ & $\begin{array}{l}-0.0768 \\
(-2.31) \\
{[-0.480]}\end{array}$ & $\begin{array}{l}-0.0939 \\
(-2.55) \\
{[-0.610]}\end{array}$ & $\begin{array}{l}-0.0960 \\
(-2.54) \\
{[-0.624]}\end{array}$ \\
\hline $\begin{array}{l}-0.00450 \\
(-0.10) \\
{[-0.0191]}\end{array}$ & $\begin{array}{l}0.00243 \\
(0.06) \\
{[0.0103]}\end{array}$ & $\begin{array}{l}-0.0448 \\
(-1.13) \\
{[-0.161]}\end{array}$ & $\begin{array}{l}-0.0228 \\
(-0.53) \\
{[-0.0817]}\end{array}$ & $\begin{array}{l}-0.0533 \\
(-1.24) \\
{[-0.203]}\end{array}$ & $\begin{array}{l}-0.0565 \\
(-1.27) \\
{[-0.215]}\end{array}$ \\
\hline $\begin{array}{l}-0.0118 \\
(-0.31) \\
{[-0.0706]}\end{array}$ & $\begin{array}{l}-0.0109 \\
(-0.28) \\
{[-0.0650]}\end{array}$ & $\begin{array}{l}-0.0627 \\
(-2.03) \\
{[-0.512]}\end{array}$ & $\begin{array}{l}-0.0620 \\
(-2.01) \\
{[-0.507]}\end{array}$ & $\begin{array}{l}-0.0695 \\
(-1.97) \\
{[-0.512]}\end{array}$ & $\begin{array}{l}-0.0702 \\
(-1.98) \\
{[-0.518]}\end{array}$ \\
\hline $\begin{array}{l}-0.075 \\
(-0.08) \\
{[-0.0267]}\end{array}$ & $\begin{array}{l}-0.132 \\
(-0.14) \\
{[-0.0468]}\end{array}$ & $\begin{array}{l}1.05 \\
(1.34) \\
{[0.349]}\end{array}$ & $\begin{array}{l}0.839 \\
(1.05) \\
{[0.280]}\end{array}$ & $\begin{array}{l}1.31 \\
(1.50) \\
{[0.439]}\end{array}$ & $\begin{array}{l}1.31 \\
(1.50) \\
{[0.441]}\end{array}$ \\
\hline $\begin{array}{l}-0.0733 \\
(-0.08) \\
{[-0.0197]}\end{array}$ & $\begin{array}{l}-0.173 \\
(-0.19) \\
{[-0.0464]}\end{array}$ & $\begin{array}{l}1.05 \\
(1.38) \\
{[0.248]}\end{array}$ & $\begin{array}{l}0.323 \\
(0.33) \\
{[0.0760]}\end{array}$ & $\begin{array}{l}1.29 \\
(1.49) \\
{[0.317]}\end{array}$ & $\begin{array}{l}1.33 \\
(1.51) \\
{[0.327]}\end{array}$ \\
\hline $\begin{array}{l}-0.217 \\
(-0.66) \\
{[-0.217]}\end{array}$ & $\begin{array}{l}-0.199 \\
(-0.60) \\
{[-0.199]}\end{array}$ & $\begin{array}{l}0.180 \\
(0.61) \\
{[0.180]}\end{array}$ & $\begin{array}{l}0.175 \\
(0.60) \\
{[0.175]}\end{array}$ & $\begin{array}{l}0.275 \\
(0.91) \\
{[0.275]}\end{array}$ & $\begin{array}{l}0.272 \\
(0.89) \\
{[0.272]}\end{array}$ \\
\hline
\end{tabular}

0.146

(1.20)

[0.0928]

$-0.933$

$(-1.24)$

[-0.145]

t-statistics are in curved parentheses below each coefficient estimate. Standardized beta coefficients are in square brackets. 
Table 3b: Can We Explain Regional Differences in Tariff Effects (1918-1937)?

Dependent variable: Annual average growth in GDP/capita during period of five years

OLS regressions, where each observation is the average value of the regressor in one country during a period of five years

Time Period

Period-initial

GDP per capita

Own tariff

(European Periphery

(dummy) $\times($ Own tariff $)$

(Core dummy) $\times($ Own tariff)

(LDC dummy) $\times$

(Own tariff)

European Periphery

dummy

Core dummy

LDC dummy

Average GDP growth among trading partners

Fraction of exports based on primary products

Tariff index for principal trading partners

Constant

$\mathrm{N}$

R-squared

Adjusted R-squared

\begin{tabular}{|c|c|c|c|c|c|}
\hline \multicolumn{6}{|c|}{ 1918-1937 } \\
\hline $\begin{array}{l}-0.000871 \\
(-2.74) \\
{[-0.479]}\end{array}$ & $\begin{array}{l}-0.000819 \\
(-2.82) \\
{[-0.450]}\end{array}$ & $\begin{array}{l}-0.000890 \\
(-2.87) \\
{[-0.475]}\end{array}$ & $\begin{array}{l}-0.000914 \\
(-2.93) \\
{[-0.488]}\end{array}$ & $\begin{array}{l}-0.000898 \\
(-2.86) \\
{[-0.473]}\end{array}$ & $\begin{array}{l}-0.00104 \\
(-3.18) \\
{[-0.547]}\end{array}$ \\
\hline $\begin{array}{l}-0.0451 \\
(-0.53) \\
{[-0.138]}\end{array}$ & $\begin{array}{l}-0.0910 \\
(-1.17) \\
{[-0.278]}\end{array}$ & $\begin{array}{l}-0.0461 \\
(-0.54) \\
{[-0.138]}\end{array}$ & $\begin{array}{l}-0.0418 \\
(-0.49) \\
{[-0.125]}\end{array}$ & $\begin{array}{l}-0.0465 \\
(-0.54) \\
{[-0.137]}\end{array}$ & $\begin{array}{l}-0.0804 \\
(-0.90) \\
{[-0.237]}\end{array}$ \\
\hline $\begin{array}{l}-0.0696 \\
(-0.64) \\
{[-0.163]}\end{array}$ & $\begin{array}{l}-0.0210 \\
(-0.21) \\
{[-0.0493]}\end{array}$ & $\begin{array}{l}-0.0961 \\
(-0.91) \\
{[-0.233]}\end{array}$ & $\begin{array}{l}-0.0984 \\
(-0.93) \\
{[-0.238]}\end{array}$ & $\begin{array}{l}-0.0961 \\
(-0.90) \\
{[-0.233]}\end{array}$ & $\begin{array}{l}-0.104 \\
(-0.98) \\
{[-0.252]}\end{array}$ \\
\hline $\begin{array}{l}0.0827 \\
(0.58) \\
{[0.141]}\end{array}$ & $\begin{array}{l}0.0768 \\
(0.59) \\
{[0.131]}\end{array}$ & $\begin{array}{l}0.0845 \\
(0.59) \\
{[0.136]}\end{array}$ & $\begin{array}{l}0.0791 \\
(0.55) \\
{[0.127]}\end{array}$ & $\begin{array}{l}0.0852 \\
(0.59) \\
{[0.137]}\end{array}$ & $\begin{array}{l}0.0760 \\
(0.53) \\
{[0.122]}\end{array}$ \\
\hline $\begin{array}{l}0.0859 \\
(0.92) \\
{[0.311]}\end{array}$ & $\begin{array}{l}0.116 \\
(1.36) \\
{[0.420]}\end{array}$ & $\begin{array}{l}0.0729 \\
(0.78) \\
{[0.265]}\end{array}$ & $\begin{array}{l}0.0752 \\
(0.80) \\
{[0.273]}\end{array}$ & $\begin{array}{l}0.0753 \\
(0.79) \\
{[0.267]}\end{array}$ & $\begin{array}{l}0.0802 \\
(0.85) \\
{[0.284]}\end{array}$ \\
\hline $\begin{array}{l}0.575 \\
(0.28) \\
{[0.0891]}\end{array}$ & $\begin{array}{l}-0.492 \\
(-0.26) \\
{[-0.0762]}\end{array}$ & $\begin{array}{l}0.718 \\
(0.35) \\
{[0.111]}\end{array}$ & $\begin{array}{l}0.441 \\
(0.21) \\
{[0.0683]}\end{array}$ & $\begin{array}{l}0.706 \\
(0.34) \\
{[0.109]}\end{array}$ & $\begin{array}{l}0.670 \\
(0.33) \\
{[0.104]}\end{array}$ \\
\hline $\begin{array}{l}0.496 \\
(0.21) \\
{[0.0574]}\end{array}$ & $\begin{array}{l}0.162 \\
(0.07) \\
{[0.0187]}\end{array}$ & $\begin{array}{l}0.480 \\
(0.20) \\
{[0.0526]}\end{array}$ & $\begin{array}{l}-0.198 \\
(-0.08) \\
{[-0.0217]}\end{array}$ & $\begin{array}{l}0.474 \\
(0.20) \\
{[0.0519]}\end{array}$ & $\begin{array}{l}0.518 \\
(0.21) \\
{[0.0568]}\end{array}$ \\
\hline $\begin{array}{l}-0.608 \\
(-1.60) \\
{[-0.608]}\end{array}$ & $\begin{array}{l}-0.700 \\
(-2.01) \\
{[-0.700]}\end{array}$ & $\begin{array}{l}-0.574 \\
(-1.52) \\
{[-0.574]}\end{array}$ & $\begin{array}{l}-0.599 \\
(-1.58) \\
{[-0.599]}\end{array}$ & $\begin{array}{l}-0.569 \\
(-1.52) \\
{[-0.569]}\end{array}$ & $\begin{array}{l}-0.637 \\
(-1.69) \\
{[-0.637]}\end{array}$ \\
\hline \multirow{3}{*}[-0.608]{} & $\begin{array}{l}0.354 \\
(4.85) \\
{[0.405]}\end{array}$ & & & & \\
\hline & & & $\begin{array}{l}-1.34 \\
(-0.82) \\
{[-0.111]}\end{array}$ & & \\
\hline & & & & & $\begin{array}{l}0.0810 \\
(1.47) \\
{[0.163]}\end{array}$ \\
\hline $\begin{array}{c}4.90 \\
(2.12)\end{array}$ & $\begin{array}{c}5.02 \\
(2.37)\end{array}$ & $\begin{array}{c}5.00 \\
(2.16)\end{array}$ & $\begin{array}{c}6.28 \\
(2.25)\end{array}$ & $\begin{array}{c}5.03 \\
(2.16)\end{array}$ & $\begin{array}{c}5.10 \\
(2.19)\end{array}$ \\
\hline 121 & 121 & 132 & 132 & 129 & 129 \\
\hline 0.0998 & 0.257 & 0.0994 & 0.104 & 0.101 & 0.117 \\
\hline 0.0355 & 0.197 & 0.0408 & 0.0382 & 0.0408 & 0.0500 \\
\hline
\end{tabular}

$\mathrm{t}$-statistics are in curved parentheses below each coefficient estimate. Standardized beta coefficients are in square brackets. 


\section{Table 4. Dependent variable: Annual average growth in GDP/capita during period of five years}

OLS regressions, where each observation is the average value of the regressor in one country during a period of five years

Time Period

Period-initial

GDP per capita

Own tariff

CYC

$\mathrm{CYC} \times$ Own tariff

Constant

1.36
$(1.81)$

0.901

(1.17)

Yes
274

$\mathrm{N}$

$\mathrm{N}$-squared

$\begin{array}{cc}\text { Yes } & \text { Yes } \\ 274 & 274 \\ 0.328 & 0.337\end{array}$

1918-1937

\begin{tabular}{|c|c|c|}
\hline $\begin{array}{l}3.40 \mathrm{E}-06 \\
(0.01) \\
{[0.00277]}\end{array}$ & $\begin{array}{l}0.000200 \\
(0.71) \\
{[0.163]}\end{array}$ & $\begin{array}{l}0.000162 \\
(0.58) \\
{[0.132]}\end{array}$ \\
\hline $\begin{array}{l}0.0447 \\
(2.87) \\
{[0.370]}\end{array}$ & $\begin{array}{l}0.0456 \\
(2.94) \\
{[0.378]}\end{array}$ & $\begin{array}{l}0.0467 \\
(3.03) \\
{[0.386]}\end{array}$ \\
\hline & $\begin{array}{l}-0.00356 \\
(-2.52) \\
{[-0.198]}\end{array}$ & $\begin{array}{l}-0.00721 \\
(-2.54) \\
{[-0.401]}\end{array}$ \\
\hline
\end{tabular}

0.0338

$$
\text { (1.38) }
$$$$
\text { [0.101] }
$$

0.0351

[0.105]

1918-1937

$\begin{array}{lll}-0.00574 & -0.00580 & -0.00582 \\ (-8.31) & (-7.87) & (-7.85) \\ {[-3.07]} & {[-3.09]} & {[-3.11]}\end{array}$

$\begin{array}{ll}0.000593 & 0.00784 \\ (0.25) & (1.04)\end{array}$

[0.0179] [0.236]

$$
\begin{aligned}
& 0.000244 \\
& (1.43) \\
& {[0.226]}
\end{aligned}
$$

0.960

(1.25)

$$
\begin{aligned}
& 22.2 \\
& (8.65)
\end{aligned}
$$$$
22.4
$$

$\begin{array}{ccc}\text { Yes } & \text { Yes } & \text { Yes } \\ 132 & 132 & 132 \\ 0.669 & 0.669 & 0.674\end{array}$

$\begin{array}{llll}1918- & 1923- & 1928- & 1933- \\ \underline{1922} & \underline{1927} & \underline{1932} & \underline{1937} \\ -0.000611 & 0.000140 & -0.000732 & 0.000356 \\ (-0.82) & (0.41) & (-3.03) & (1.36) \\ {[-0.353]} & {[0.0983]} & {[-0.462]} & {[0.185]} \\ & & & \\ 0.0198 & 0.0495 & -0.0276 & -0.00879 \\ (0.18) & (1.07) & (-0.52) & (-0.17) \\ {[0.0424]} & {[0.148]} & {[-0.0795]} & {[-0.0285]} \\ & & & \\ -0.0185 & 0.0273 & -0.0267 & 0.0238 \\ (-0.67) & (2.61) & (-0.74) & (1.29) \\ {[-0.465]} & {[1.17]} & {[-0.641]} & {[0.695]} \\ & & & \\ 0.000682 & -0.00212 & 0.000905 & -0.00243 \\ (0.33) & (-3.66) & (0.63) & (-2.23) \\ {[0.224]} & {[-1.52]} & {[0.493]} & {[-1.28]} \\ & & & \\ 2.21 & 1.51 & 1.63 & 0.643 \\ (1.59) & (1.39) & (1.38) & (0.43) \\ & & & \text { No } \\ \text { No } & \text { No } & \text { No } & 33 \\ 30 & 34 & 35 & 0.543 \\ 0.0505 & 0.184 & 0.279 & \end{array}$

t-statistics (using White standard errors) are in parentheses immediately below each coefficient estimate. Standardized beta coefficients are in square brackets. 
Table 5. Average changes in the world economic environment between the late $19^{\text {th }}$ and the late $20^{\text {th }}$ centuries.

$\frac{1870-1913}{\mu \quad \sigma} \quad \frac{1970-1998}{\mu \quad \sigma} \quad \begin{gathered}\text { Period-to- } \\ \text { Period } \mu \\ \text { Change }\end{gathered}$

Average own tariff rate, $\%$

Annual own growth in GDP/capita, \%

Average trading partner tariff, $\%$

Average trading partner annual GDP growth, \% 2.34
14.26

1.28

9.86

8.83

0.66

5.10

0.70
12.59

1.32

5.59

3.52
$8.17-1.67$

1.890 .04

$2.37 \quad-4.27$

$0.34 \quad 1.18$ 
Figure 1. Unweighted World Average Own Tariff, 35 countries, \%

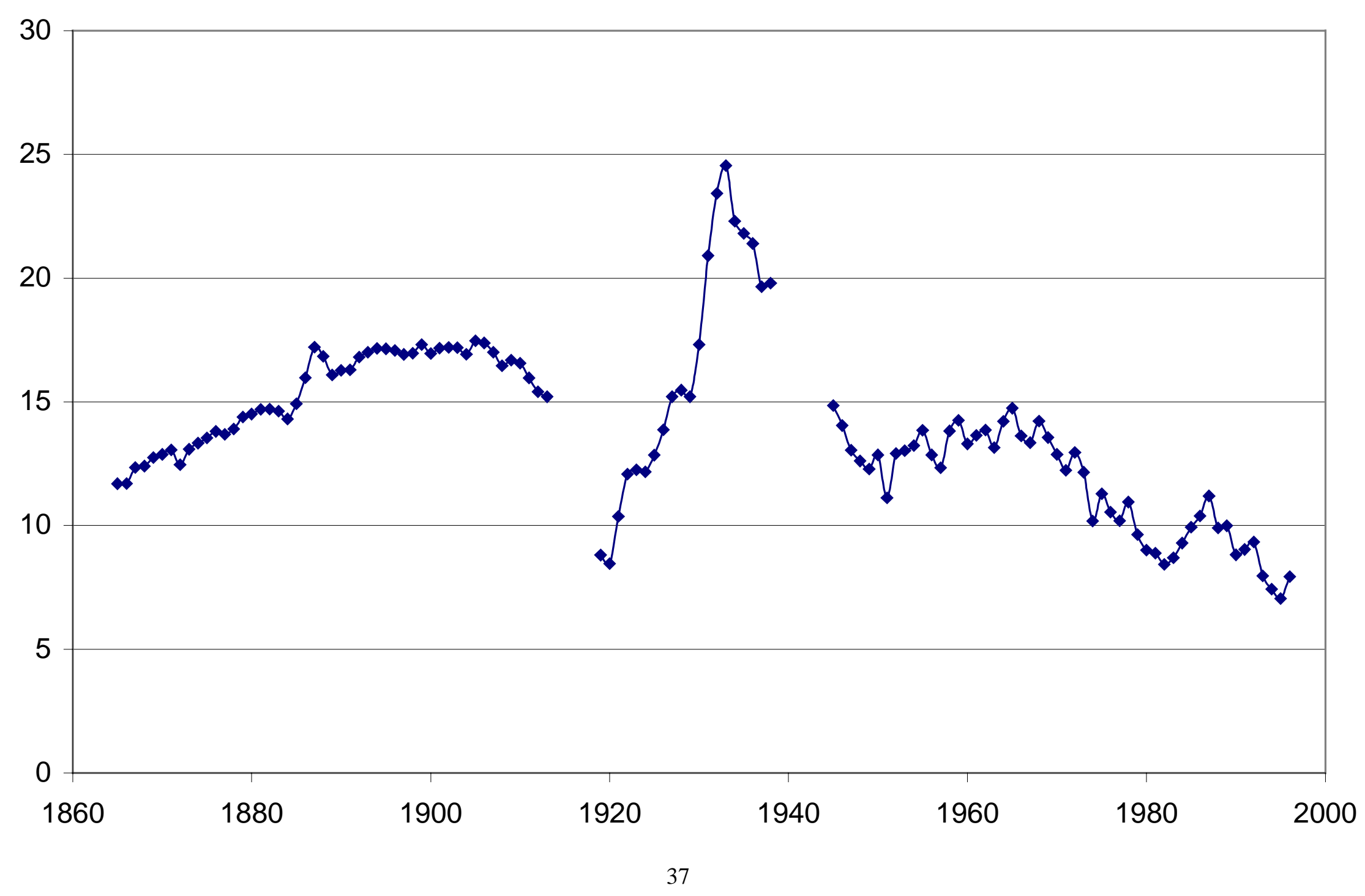


Figure 2. Unweighted Regional Average of Own Tariffs, \%

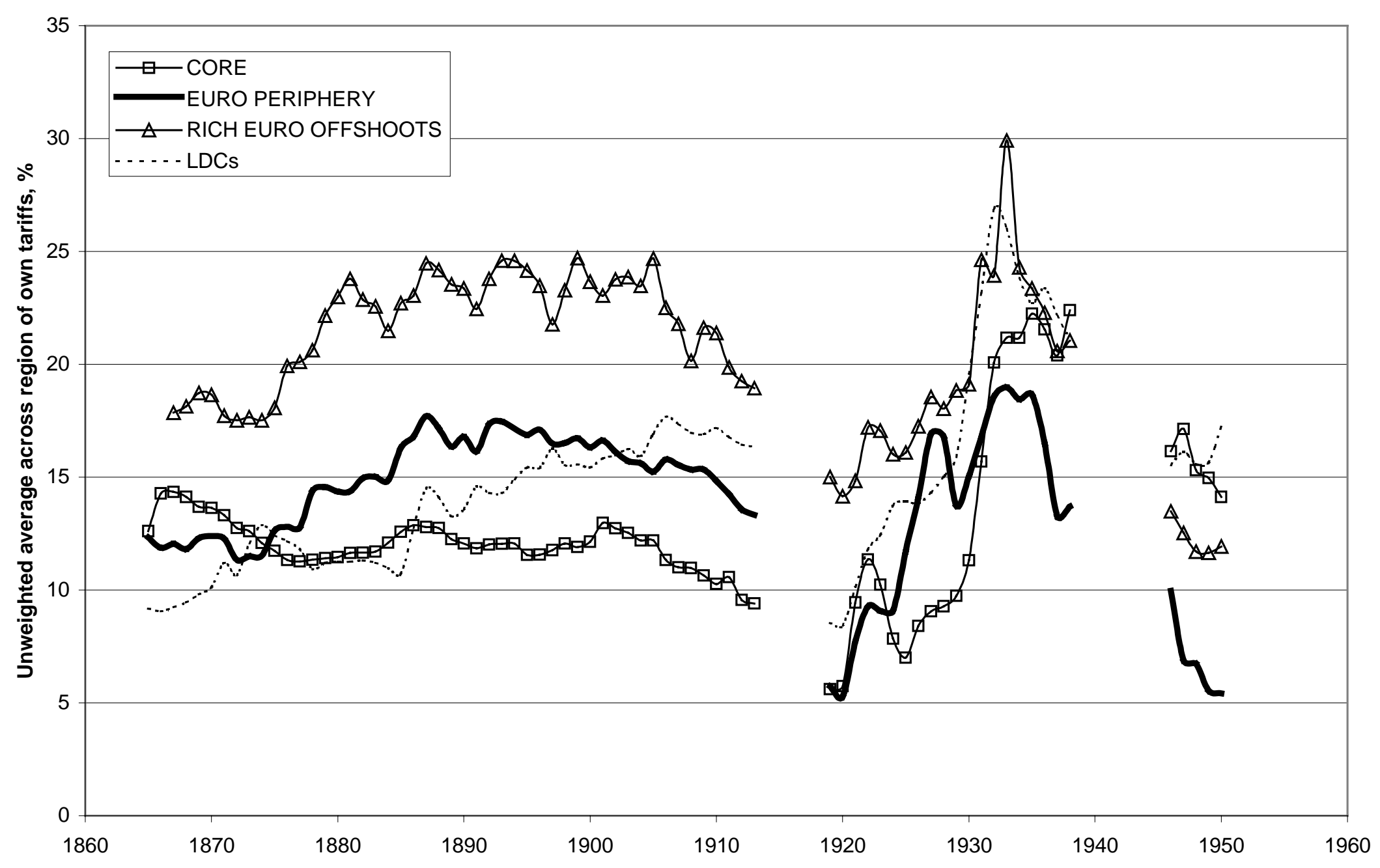


Figure 3. Unweighted Regional Average of Index of Principal Trading Partners Tariffs, $\%$

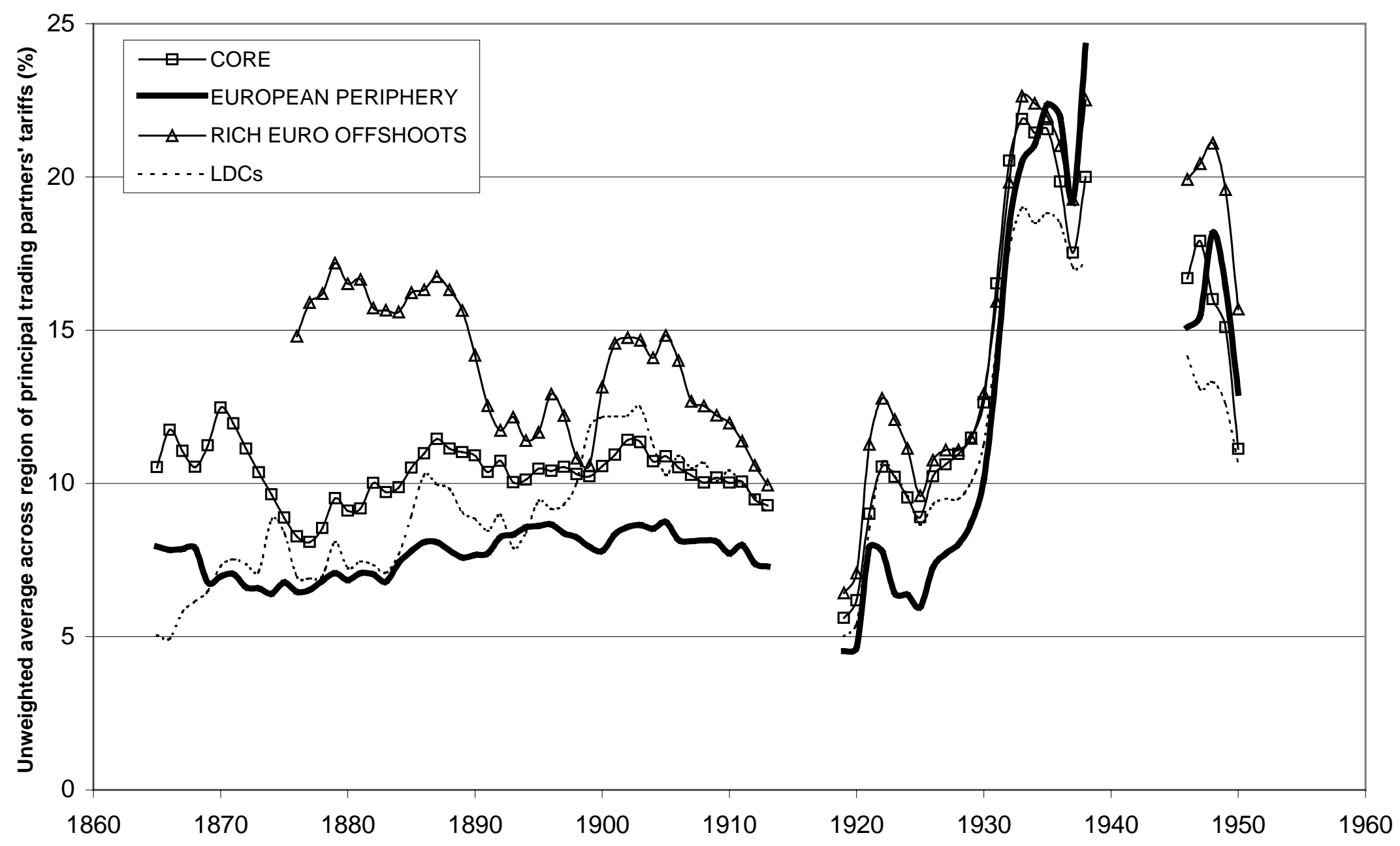


Figure 4. The partial residual scatterplot of Table 1, column 1.

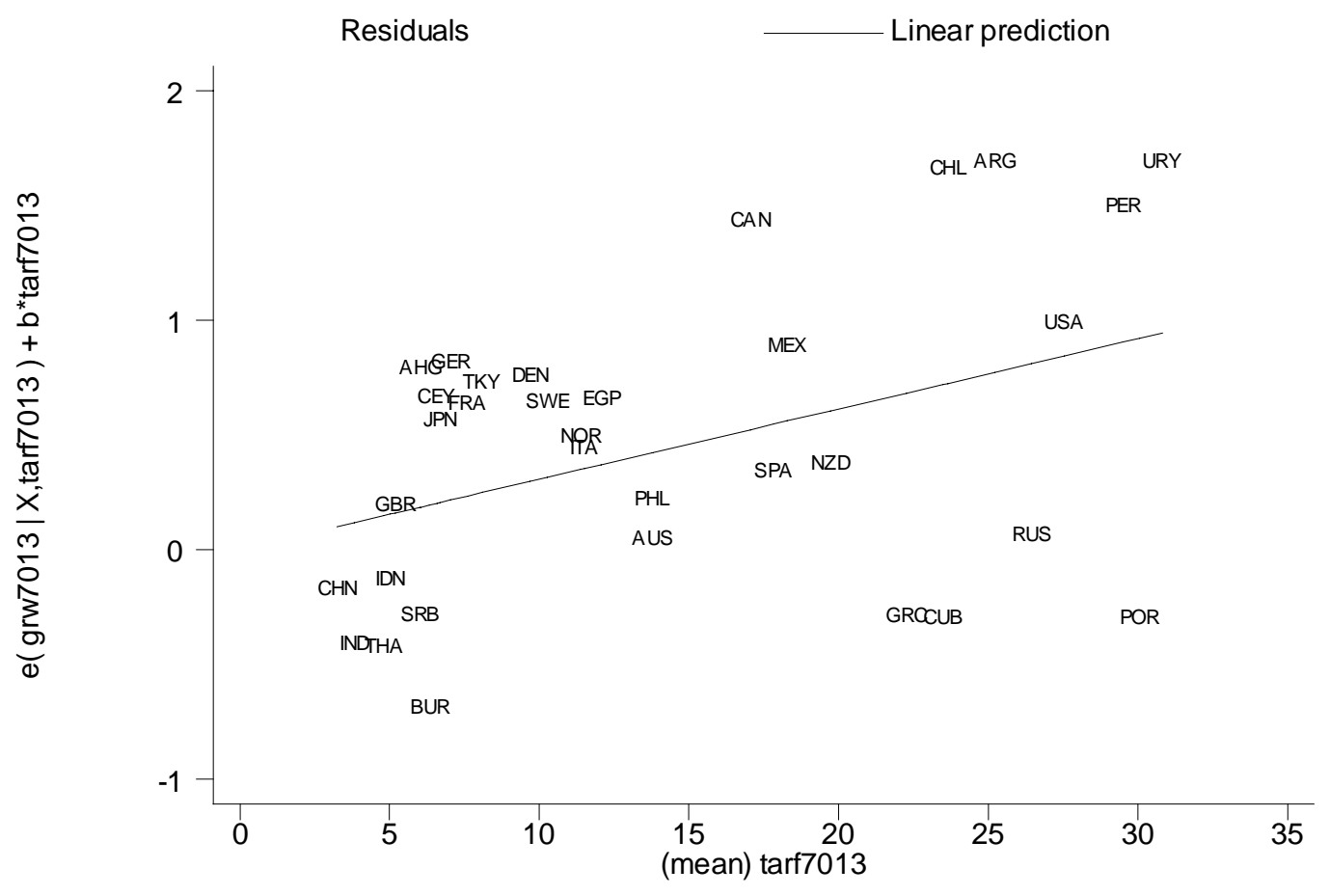

Figure 5. The partial residual scatterplot of Table 1, column 6.

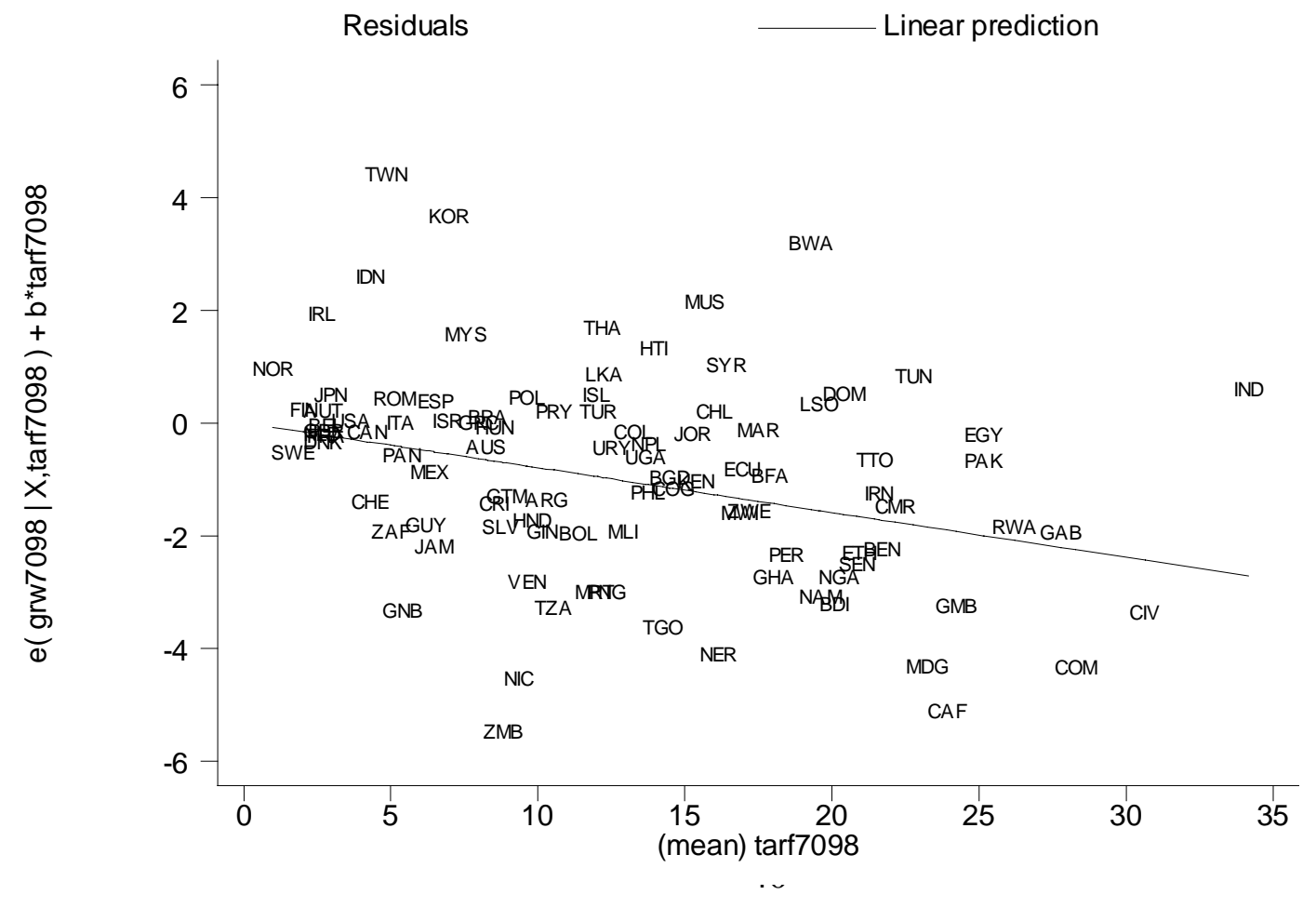


Figure 6. A prisoners' dilemma in tariff policy

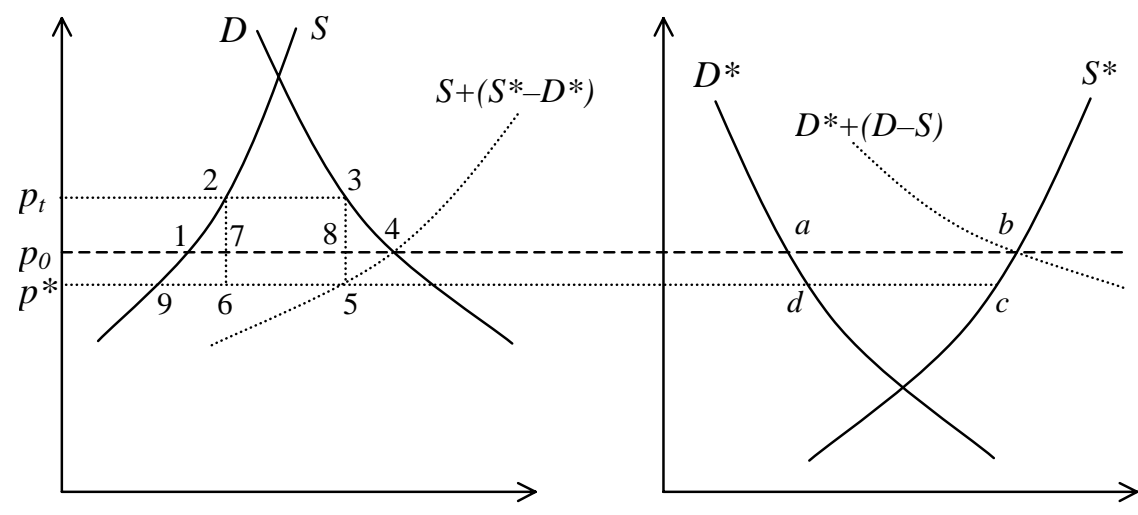

Importer

Exporter 
Figure 7. The partial residual scatterplot of own tariffs from Table 1, column 7.

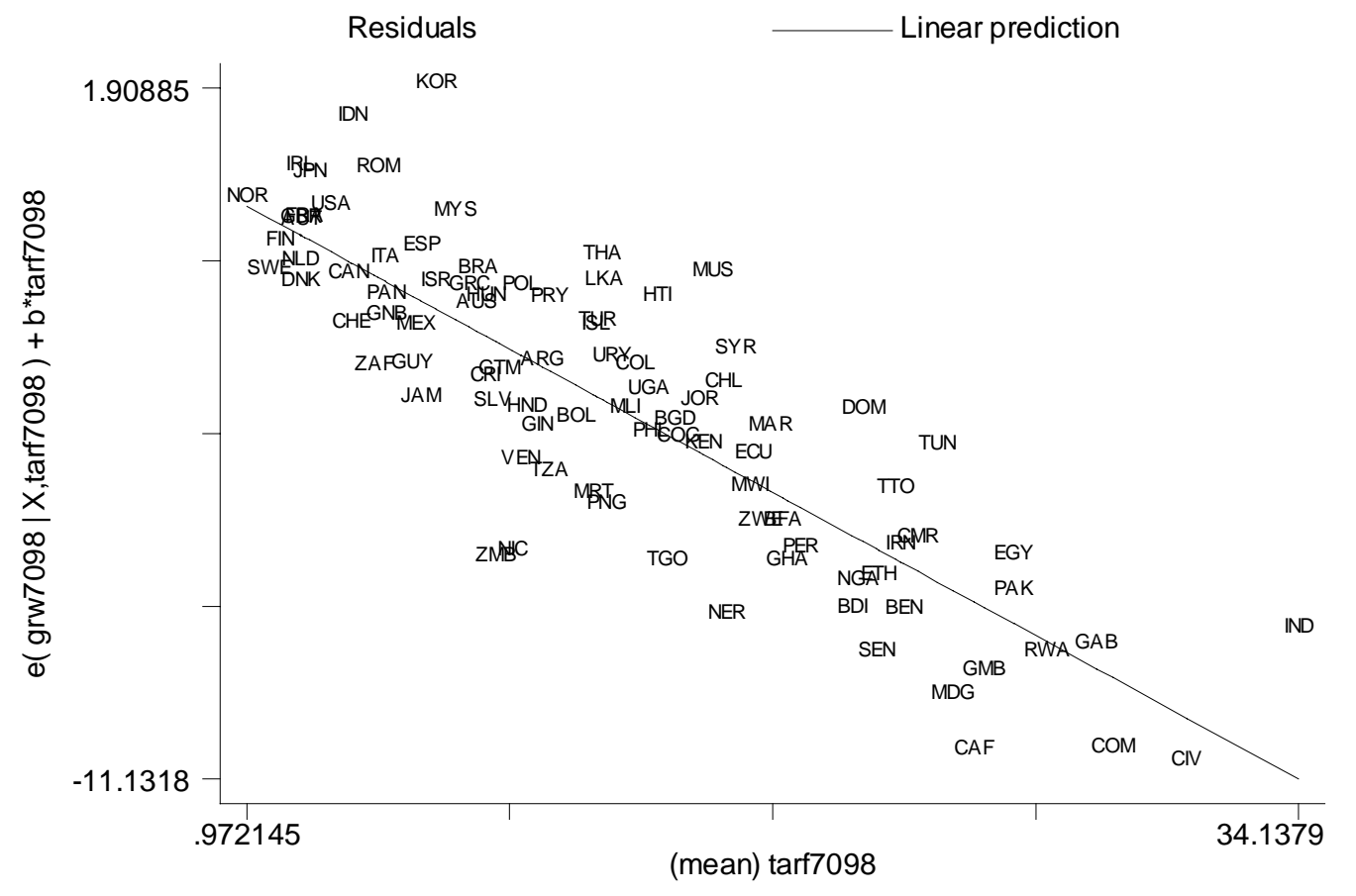

Figure 8. The partial residual scatterplot of own trading partner tariffs from Table 1, column 7.

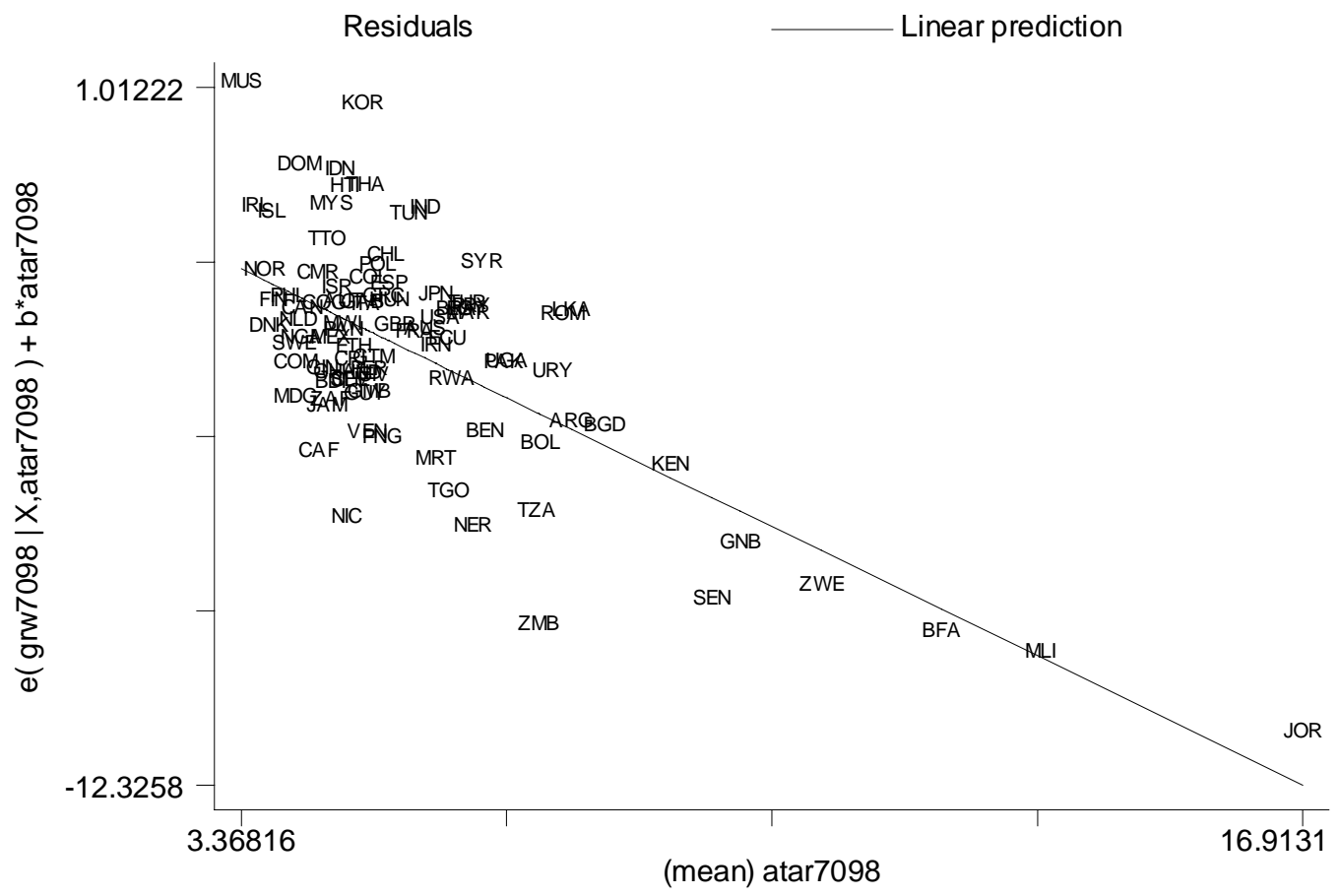


Figure 9. The partial residual scatterplot of the interaction term (own tariff) $\times$ (trading partner tariff) from of Table 1, column 7.

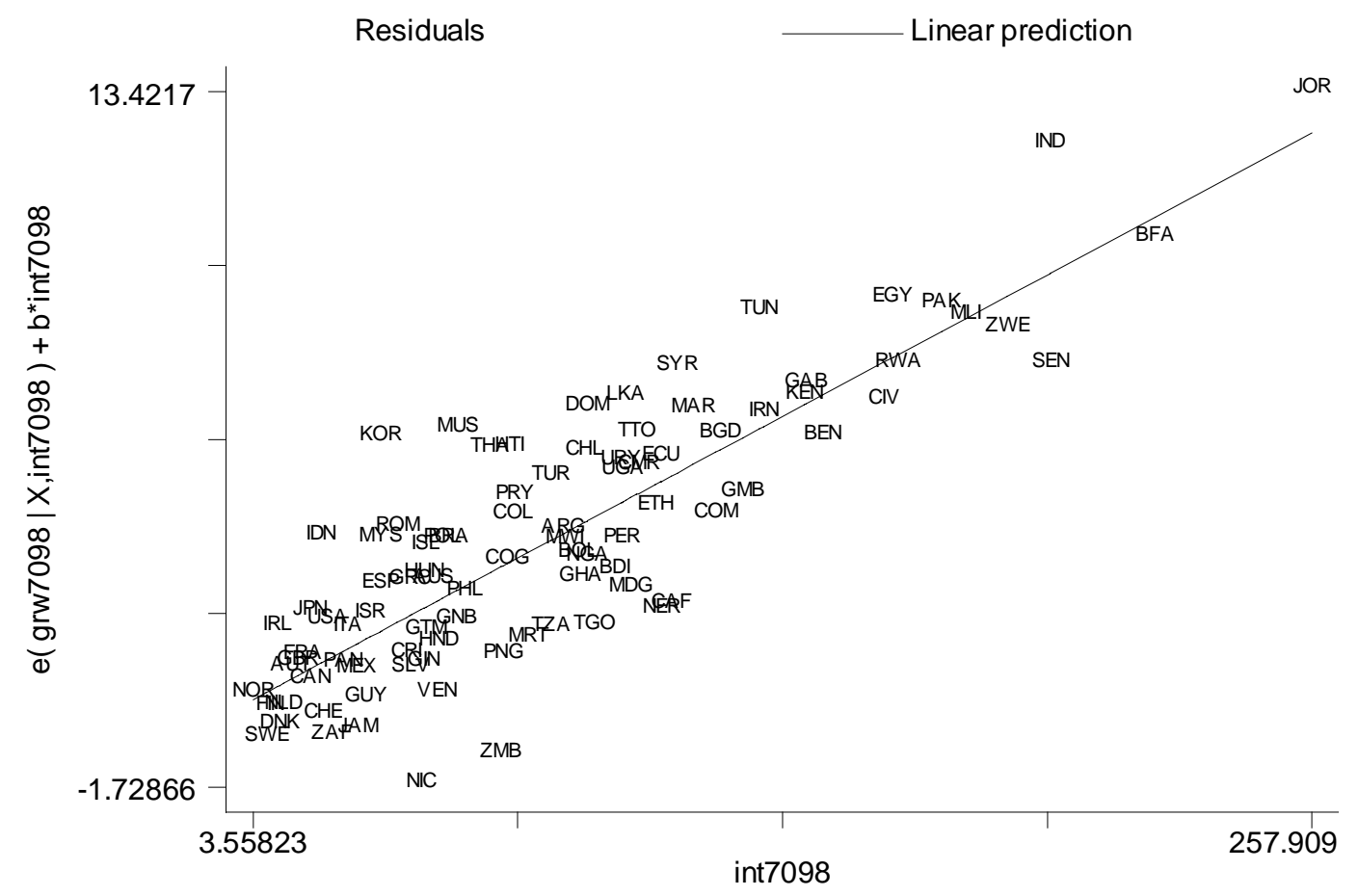


Figure 10. A graphical representation of the results in Table 1, column 7.

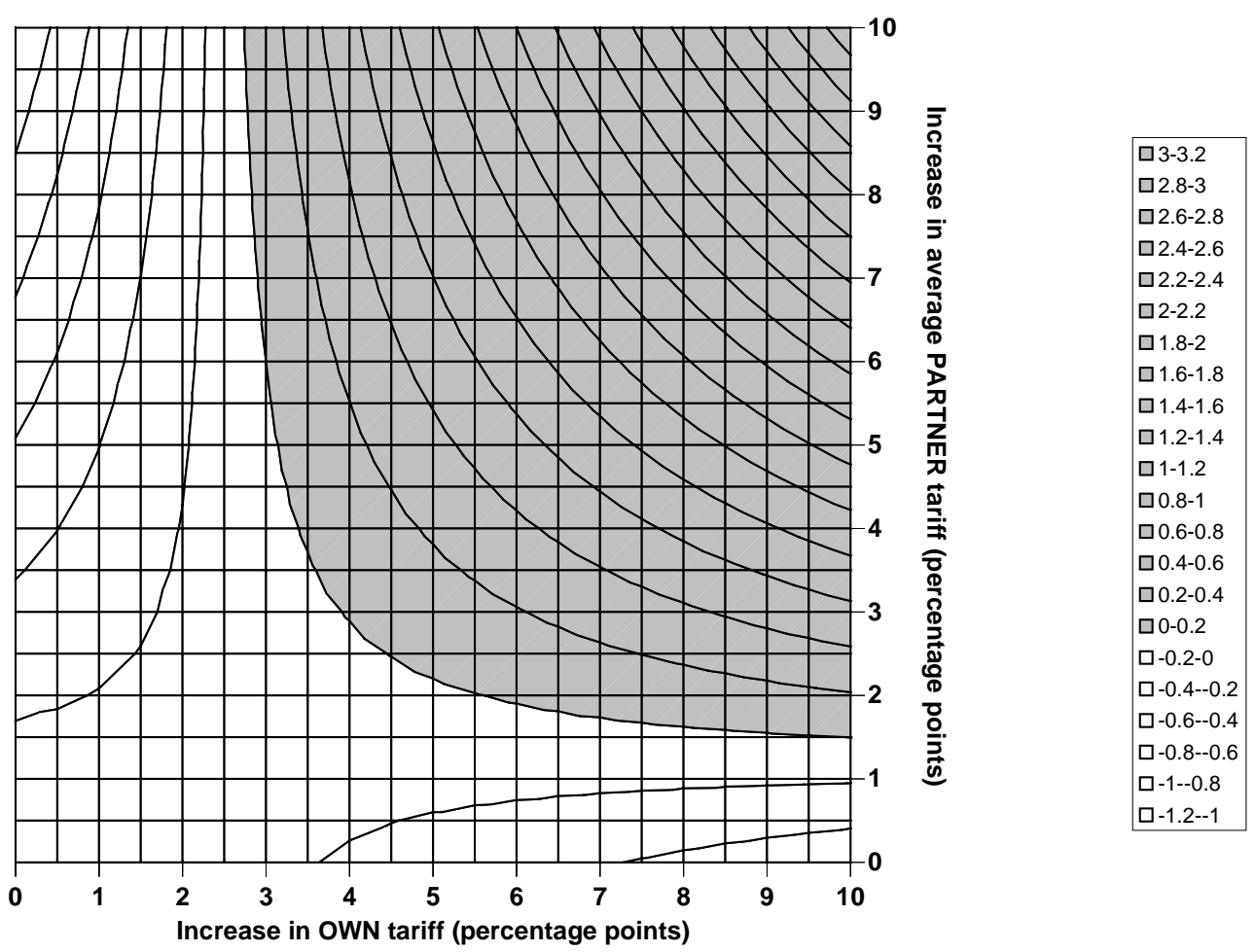

Z-axis (contour lines) represent predicted increase in growth due to simulated increases in own tariff or partner tariffs. Gray shading represents positive changes in growth, white represents negative changes. Each contour line shows a $0.2 \%$ change in annual GDP per capita growth. 


\section{Data Appendix}

\section{PART I: BEFORE 1950}

Data for most variables for the period 1865-1913 come from Michael A. Clemens and Jeffrey G. Williamson, "Where did British Foreign Capital Go?" NBER Working Paper 8028, National Bureau of Economic Research, Cambridge, Massachusetts (December 2000), which has a comprehensive appendix describing sources and methods. What follows dwells on 1914-1940 and on variables either missing from Clemens and Williamson or having been replaced by another source.

A number of sources are used frequently. They are: Arthur S. Banks, Cross-National Time Series, 1815-1973, [Computer File], ICPSR ed. (Ann Arbor, Michigan: Inter-University Consortium for Political and Social Research, 1976); Brian R. Mitchell, International Historical Statistics, Europe, 1750-1988 (New York: Stockton Press, 1992); Brian R. Mitchell, International Historical Statistics: The Americas, 1750-1988 (New York: Stockton Press, 1993); Brian R. Mitchell, International Historical Statistics: Africa, Asia \& Oceania, 1750-1993 (New York: Stockton Press, 1998).

\section{Average Tariff Rates: Import Duties over Imports}

Average tariff rates are calculated as the total revenue from import duties divided by the value of total imports in the same year. In some cases, the sources used do not distinguish between import and export duties, and report total customs duties only. Total customs duties are used in the calculation of average tariff rates (instead of import duties) for countries where the value of export duties has historically been an insignificant share of total customs duties. Sometimes, the value of import duties collected is reported for fiscal years, while import data generally refer to calendar years. While making a consistent effort to compare calendar year duties to calendar year imports, in cases where calendar year duties figures are unavailable, fiscal year duties are divided by calendar year imports to calculate average tariff. (In these instances, fiscal year import duties are assumed to belong to the calendar year in which most of the fiscal year falls).

Argentina: Average tariff figures for 1914-1930 are taken from Rosemary Thorp, "Economy, 1914-29," in Leslie Bethel (ed), Latin America: Economics and Society 1870-1930 (Cambridge: Cambridge University Press, 1989), p. 77, Diagram: “Tariffs as a percentage of import value, 1910-30.” Figures for 1931-1937 come from Memoria de la Contaduria General de la Nacion, Volume 1 (Buenos 
Aires: Ministerio de Hacienda, various issues), 1931: p. 43, 1932: p. 115, 1934: p. 137, 1935: p. 159, 1937: p. 177. Import duties for 1933 and 1936 and import figures for 1931-1937 are taken from $E l$ Comercio Exterior Argentino (Buenos Aires: various issues), 1933: p. 57, 1937: p. 61. Data for 1938-40 are from the United Nations Statistical Yearbook (Statistical Office of the United Nations, Department of Economic Affairs, New York, 1951), with imports on pp. 364-88, and customs duties on pp. 474-520. The yearbook asserts that "wherever the distinction is of quantitative importance, customs duties are subdivided into import and export duties" (p. 472).

Australia: Customs import duties and total imports are reported in the Official Year Book of the Commonwealth of Australia (Canberra: Commonwealth Bureau of Census and Statistics, Government Printer, various issues), 1915: p. 567, 1916: p. 595, 1917: p. 591, 1918: p. 616, 1919: p. 596, 1920: p. 616, 1921: p. 533, 1922: p. 502, 1927: p. 216 and 352, 1929: p. 227 and 350, 1933: p. 258, 1937: p. 520, 1941: p. 678. Import duties after 1930 include the so-called "primage duty" collected on Australian imports. Average tariff rates used in Clemens and Williamson (2000) were replaced for 1901-1913 with annual figures from Mitchell (1998).

Austria: Figures for 1922-1937 are taken from Mitchell (1992).

Brazil: Figures for 1914-1930 come from Bethel (1989), p. 77 (Diagram: "Tariffs as a percentage of import value, 1910-30"). For 1931-1936, import duties (“direitos de importacao para consumo”) are taken from Contadoria Central da Republica, Balanco Geral da Uniao, 1936 (Imprensa Nacional, Rio de Janeiro, 1937), p. 136, while the value of total imports are from Comercio Exterior do Brazil, 1933-37 (Rio de Janeiro: Servico de Estadistica Economica E Financeira do Tresouro Nacional, Ministerio da Fazenda), p. 3. The ratio of "import taxes" and imports for 1937-1940 is calculated from A. K. Ludwig, Brazil: A Handbook of Historical Statistics (Boston: G.K. Hall \& Co., 1985), p. 314 (imports) and p. 354 (“import taxes").

Burma: Imports are reported annually and customs duties for every fifth year in Teruko Saito and Lee Kin Kiong, Statistics on the Burmese Economy (Singapore: Institute of Southeast Asian Studies, 1999), p. 175 (imports) and p. 201 (customs duties). Thus, average tariff rates are calculated for every fifth year and the missing years are interpolated geometrically.

Canada: Figures for 1867-1913 come from Mitchell (1993). For 1914-40, figures are taken from M. C. Urquhart and K. A. H. Buckley, Historical Statistics of Canada (Cambridge: Cambridge University Press, 1965), p. 173 (imports) and pp. 197-8 (“customs import duties”).

Ceylon: Figures for 1925-1940 come from Thirty Years of Trade Statistics of Ceylon (1925-54), 
(Colombo: Department of Commerce, Part 1, 1955), p. 1 ("merchandise imports") and p. 2 ("customs duties on imports"). Average tariff rates for 1921 and 1922 are calculated using the Annual General Report (Colombo: Government Record Office, various issues), 1922: pp. 21-22 and 1923: p. 10. According to the figures in the Annual General Report, the value of export duties in Ceylon was almost exactly one third of the value of import duties in 1921-1923. Therefore, Ceylon's average tariff rate for 1914-1920 is estimated as follows: customs duties reported in Patrick Peebles, A Handbook of Historical Statistics (Boston: G.K. Hall \& Co., 1982), pp. 236-7, are multiplied by : to get an estimated value of import duties; then the estimated import duties are divided by the value of merchandise imports given in the Thirty Years of Trade Statistics of Ceylon (1955), p. 1.

Chile: Figures for 1914-1930 are taken from Markos J. Mamalakis, Historical Statistics of Chile (New York: Greenwood Press, 1989), vol. 6, p. 206. Figures for 1940-1950 are from Mamalakis, vol. 1, pp. $67-8$ (import duties) and p. 85 (imports). Figures for 1931-1939 are calculated as follows. Customs duties for 1930-1940 are from Mamalakis, vol. 6, pp. 506-7, while imports are found in Banks (1976) and converted to current pesos with the exchange rates in Bryan Taylor, Encyclopedia of Global Financial Markets, Seventh Edition (Los Angeles: Global Financial Data, 2000). According to Mamalakis, vol. 1, pp. 67-8, the value of export duties in Chile was consistently well under $1 \%$ of that of import duties, so using the sum of import and export duties for 1931-1939 in our calculations seems justified. Figures for 19311939 are estimated assuming that average tariff levels between 1930-1940 deviate from their trend (based on Mamalakis' figures for the years 1930 and 1940) in the same way (percentage-wise) as the tariff levels calculated from the Mamalakis customs duties and Banks imports deviate from their trend.

China: The treaties of Nanking (1843) and Tientsin (1858), as well as other similar treaties, limited the Chinese ad valorem tariff rate on imports from essentially all of Europe to 5\%. However, the treaties (and their revisions in 1870, 1902, 1917, and 1922) did not set ad valorem tariffs. Rather, they set specific nominal duties that, although initially equivalent to a $5 \%$ ad valorem tariff, rapidly declined in effective value as prices rose (C. F. Remer, The Foreign Trade of China (Shanghai: The Commercial Press Ltd., 1926), pp. 171-81). "The average effective rates were often below three percent and were never above four percent even in the years immediately following the revisions" (Yu-Kwei Cheng, Foreign Trade and Industrial Development of China (Seattle, Wash.: The University Press, 1956, pp. 8-13). For this reason it is assumed that import-duties-over-imports for China started at $4 \%$ in each year and declined at a constant rate to $2.5 \%$ in the year immediately preceding the next revision." (Clemens and Williamson 2000). Due to China's joining World War I, one such tariff revision took place in 1918. "But that revision 
proved inadequate since the yield at the time of the Washington Conference of 1921-1922 was estimated at only about 3 per cent. The Conference agreed to immediate revision to an effective 5 per cent" (Arthur N. Young, China's Nation-Building Effort, 1927-37 (Stanford, Cal.: Hoover Institution Press, 1971), p. 18). Finally, through negotiations the Nationalist government obtained tariff autonomy by 1929, which changed Chinese tariffs greatly. Young (1971) reports imports (pp. 492-3) and import duties (p. 52) for the period 1927-1937. The average tariff rates take account of Manchuria's foreign trade until 1931.

Colombia: Figures for 1924-40 are taken from the Anuario General de Estadistica (Bogata: Imprenta Nacional, various issues), which report customs duties (impuestos aduanas y recargos, 1935: pp. 296-7, 1951-1952: p. 281) and imports (1929: p. 364, 1935: p. 202, 1951-1952: p. 173).

Cuba: Figures for 1928-40 are taken from S. Schroeder, Cuba: A Handbook of Historical Statistics (Boston: G.K. Hall \& Co., 1982), p. 470.

Denmark: Figures for 1865-1913 come from Mitchell (1992). Figures for 1914-40 are taken from Hans Chr. Johansen, Dansk Historisk Statistik (Danish Historical Statistics), 1814-1980 (Copenhagen: Gyldendal, 1985), where total merchandise imports (“samlet vareindforsel”, pp. 196-7) and customs duties (“told", pp. 327 and 330) are reported.

Egypt: Figures for 1884-1935 are taken from the Annual Statement of the Foreign Trade of Egypt (Cairo: Statistical Department, Ministry of Finance, 1935), where "duty collected on imports" (of merchandise) is given on p. 6. Figures for 1938-1940 are from the United Nations Statistical Yearbook (1951). Figures for the period 1936-1937 are obtained through geometric interpolation.

France: Figures for 1865-1913 are from Mitchell (1992). Figures for 1914-1940 are taken from the Annauire Statistique, (Paris: Ministere des Finances et de Affaires Economiques, Impremerie Nationale, 1951), which reports total imports (pp. 190-1) and import duties (“droits d'importation”, p. $321)$.

Germany: Figures for 1880-1940 come from Mitchell (1992). Nonetheless, the following sources were also used to convince ourselves of the validity of the Mitchell figures: Deutsche Wirtschaftskunde (Berlin: Statistischen Reichsamt, Verlag von Reimer, Hobbing, 1933), pp. 119, 316, 336; Otto Nathan, The Nazi Economic System (Durham, North Carolina: Duke University Press, 1944), p. 320; Statistisches Jahresbuch für das Deutsche Reich (Berlin: Statistisches Reichsamt, various issues). Since the fragmented data in these sources on imports ("Einfuhr") and customs import duties ("Zölle" or "Zollerträge”) match the figures in Mitchell (1992), the latter was used 1880-1940 for continuity.

Greece: Figures for 1911-1939 are taken from Statistique du Commerce de La Grece avec Les 
Pays Etranges, Volume I. (Athens: Impremerie Nationale, 1939), which gives imports (p. 4) and import duties (“droits d'importacion,” p. 31).

India: Figures for 1910-1934 come from the Statistical Abstract of British India (London: His Majesty's Stationery Office, various issues), 1910-1920: pp. 62 and 152-3, 1920-1930: pp. 212-4 and 5345, 1926-1936: pp. 404-6 and 824-5. In this source, duties on imports by sea and total imports by sea are reported. The use of sea trade data to calculate average tariff levels seems justified given that customs revenues from land trade represented only about $0.5 \%$ of the customs duties on sea trade, and land imports were well under 10\% of sea-borne imports. Figures for 1935-1940 are from the Review of the Trade of India (Delhi: Department of Commercial Intelligence and Statistics, various issues), 1936-1937: pp. 32 and 263, 1937-1938: pp. 78 and 277, 1940-1941: pp. 101 and 249.

Indonesia: Figures for 1914-1939 are from W. L. Korthals Altes, Changing Economy in Indonesia: Volume 12a, General Trade Statistics 1822-1940, (Amsterdam: Royal Tropical Institute, 1991), pp. 54-6 (imports) and pp. 187-8 (import duties). Figures for 1940 are taken from the Statistical Pocket Book of Indonesia (Jakarta: Biro Pusat Statistik, 1957), p. 99 (imports) and p. 173 (import duties).

Italy: Figures for 1865-1913 are from Mitchell (1992). For 1914-1940, the data come from Thelma Liesner, One Hundred Years of Economic Statistics (New York: Facts on File, 1989), pp. 244-7.

Japan: Figures for 1865-1891 are from Mitchell (1998). Figures for 1892-1940 are taken from Japan Statistical Yearbook (Tokyo: Sorifu, Tokeikyoku, 1949), p. 471. Figures for 1866, and 1893-1896 are obtained through geometric interpolation.

Mexico: Figures for 1925-1937 come from the Anuario Estadistico (Mexico D. F.: Estados Unidos Mexicanos Secretario de la Economia Nacional Direccion General de Estadistica, various issues), reporting Mexican import duties (“impuestos a la importation,” 1930: p. 517, 1938: pp. 280-1, 1940: p. 741 ) and imports (1938: p. 247, 1940: p. 654). Figures for 1938-1940 are from the United Nations Statistical Yearbook (1951). Figures for the extended civil war period, 1913-1924, are estimated through geometric interpolation.

New Zealand: Figures are taken from the Official Year Book of New Zealand (Wellington: Government Printer, various issues), including 1894: p. 132 and endsheet, 1928: p. 341, 1932: p. 281, 1935: p. 233, 1938: p. 270, 1941: p. 249. Figures for 1865-1885 were estimated by assuming that tariff revenue represented the same average fraction of total tax revenue during 1865-1885 as it did 1886-1892 (i.e. roughly $70 \%$ ). The assumption is justified by the facts that a) this fraction was essentially constant on the period 1886-1892, and that b) this fraction back in 1851-1852 was also roughly $70 \%$ (endsheet of the 
1894 edition of the Official Year Book has figures for 1851-1852).

Norway: Figures for 1865-1940 are from Mitchell (1992). The Historisk Statistikk (Oslo: Central Bureau of Statistics of Norway, 1978), pp. 261 and 446, was also used to check the validity of Mitchell's data.

Peru: Figures for 1914-1930 come from Bethel (1989), p. 77 (Diagram: "Tariffs as a percentage of import value, 1910-30"). Figures for 1931-37 are taken from the Extracto Estadistico del Peru (Lima: Preparado por la Direccion Nacional de Estadistica, 1938) reporting customs duties ("impuestas aduanas," p. 402) and total imports (p. 212). Data for 1938-40 are from the United Nations Statistical Yearbook (1951).

The Philippines: Figures for 1914-1940 come from the Annual Report of the Insular Collector of Customs (Manila: Bureau of Printing, 1937 and 1940), where import duties (1940: pp. 359-60) and imports (1937: pp. 66-7, 1940: p. 15) are presented.

Portugal: Average tariff levels are taken from Joao Luis Cesar das Neves, The Portuguese Economy: A Picture in Figures (Lisbon: Universidade Catolica Editora, 1994). The graph on p. 149 illustrates "Import Tax/Import" values for Portugal for the period 1836-1990.

Russia: Customs revenue to the central government of the Soviet Union and total imports from all international borders, 1924-28, are taken from the Statisticheskii Spravochnik SSSR 1928 (USSR Statistical Handbook 1928), Soiuz SSR TSentral'noe Statisticheskoe Upravlenie (USSR Central Statistical Agency), Moscow, 1929, pp 570, 713.

Yugoslavia (Serbia): Tariff figures are taken from W. S. Woytinsky and E. S. Woytinsky, World Commerce and Governments - Trends and Outlook (New York: The Twentieth Century Fund, 1955), p. 277, for benchmark years between 1913-1931. However, it has been noted that the average tariff levels in this source most likely refer to import-duties-over-dutiable-imports ratios, and thus are consistently higher than what other sources suggest. Therefore, Yugoslav tariff rates given in Woytinsky and Woytinksy (1955) have been altered: the benchmark values were converted to import-duties-over-total-imports estimates. The sum of tariff levels for Austria, France, Germany, Italy, Spain, and Sweden given in Woytinksy and Woytinsky (1955) in each benchmark year was divided by the sum of tariff levels for the same countries and years found in other sources (cited in this Data Appendix for each of the countries). Then, the Yugoslav tariff rates reported in Woytinksy and Woytinsky (1955) were divided by this ratio, in order to estimate Yugoslav import-duties-over-total-imports. Missing years have been geometrically interpolated. Also, it has been noted that the Serbian tariff level estimates used in Clemens and Williamson 
(2000) also refer to import-duties-over-dutiable-imports. Therefore, the Clemens and Williamson Serbian tariff figures for 1865-1913 were linked to the tariff levels calculated above for 1913-1931, yielding an estimate for Serbian import-duties-over-total-imports ratios for 1865-1913.

Spain: Figures for 1865-1940 come from two sources: imports are taken from L. Prados de la Escosura, El Progreso economico de Espana, 1850-2000 (Madrid: 2002), while "tariff revenue" is taken from F. Comin, Fuentes cuantitativas para el estudio del sector publico en Espana. (Madrid: 1985).

Sweden: Average tariff figures for 1865-1910 are from Mitchell (1992). Figures for 1911-1940 are taken from Handel (Stockholm: Sveriges Officiella Statistik, various issues), where customs duties as a percentage of imports (“Tulluppbörd i \% av införseln”) are given in various issues (1917: p. 34, 1926: p. 28, 1936: p. 32, 1945: p. 37, 1951: p. 34).

Thailand: Figures for 1914-1940 are taken from Constance M. Wilson, Thailand: A Handbook of Historical Statistics, (Boston: G.K. Hall \& Co., 1983), pp. 210-1 (imports) and pp. 242-4 (customs duties).

Turkey: Figures for 1923-1940 come from the Annuaire Statistique (Ankara: Republique Turque, Office Central De Statistique, various issues), which report imports (1928: pp. 103-6, 1932-1933: p. 250, 1938-1939: p. 231, 1948: p. 396, 1951: p. 357) and import taxes ("taxes douanieres," i.e. "gümrük resmi," 1928: pp. 156-7, 1930: p. 310, 1932-1933: p. 302, 1938-1939: pp. 276-7, 1942-1945: p. 385, 1948: p. 434, 1950: p. 245, 1951: p. 324).

United Kingdom: Figures for 1865-1940 are taken from Brian R. Mitchell, British Historical Statistics (Cambridge: Cambridge University Press, 1988), where imports (p. 453) and customs revenue (pp. 582-4) are reported annually.

United States: Figures for 1865-1940 come from Woytinsky and Woytinsky (1955), pp. 263-4. The reported data are "duties as percentage of total imports" (emphasis added). Thus, the Woytinsky and Woytinsky US series does not have the upward bias mentioned previously for the case of Yugoslavia. Some missing years falling in the period 1865-1910 are geometrically interpolated.

Uruguay: Figures for 1913-1940 are taken from Anuario Estadistico (Montevideo: Ministerio de Hacienda, Direccion General de Estadistica y Censos, various issues), where import duties (“derechos de aduana s. importacion") and imports are reported annually. Tariff figures for two missing years, 1923 and 1939, are estimated by geometric interpolation.

\section{Population}

For the entire period under observation, annual estimates of the population (in thousands) of 
Argentina, Australia, Austria, Brazil, Canada, Chile, China, Colombia, Cuba, Denmark, France, Germany, Greece, Italy, Mexico, New Zealand, Norway, Peru, Portugal, Russia, Spain, Sweden, Thailand, United Kingdom, Uruguay, USA, and Yugoslavia are given in Banks (1976). Missing war years 1914-1918 are derived by geometric interpolation.

Population for Ceylon (Sri Lanka) is taken from Mitchell (1998), while that for Burma, Egypt, India, Indonesia, Japan, Philippines, and Thailand are taken from Maddison (1995).

Population for Australia before 1901, Cuba before 1902, Germany before 1867, New Zealand before 1907, and Serbia before 1878 are not reported in Banks (1976). For these, the population figures in Clemens and Williamson (2000) are used, linked to the Banks figures. For Ceylon and India, the figures used in Clemens and Williamson for 1865-1913 are linked to the post-1914 series.

\section{GDP and GDP per Capita}

For most countries, gross domestic product per capita (in 1990 US dollars) is taken from Angus Maddison, Monitoring the World Economy 1820-1992 (Paris: Development Center of the Organization for Economic Cooperation and Development, 1995). Data for a small number of missing years are geometrically interpolated.

For five countries not reported in Maddison (1995)—Ceylon, Cuba, Egypt, Portugal and Uruguay, GDP per capita is calculated by dividing a country's income (in 1990 US dollars) by population in every year. Sources of the population data have been described above, and the sources of the income estimates follow.

GDP per capita for Ceylon in 1914 is benchmarked relative to India's in 1914 by the ratio (1.95) given in Burnham O. Campbell, "Development Trends: A Comparative Analysis of the Asian Experience," in Naohiro Ogawa et al., eds., Human Resources in Development Along the Asia-Pacific Rim (New York: Oxford University Press, 1993). The same ratio had declined to 1.52 by 1948 according to United Nations Statistical Yearbook 1949-50 (New York: 1950), pp. 21-2 and 406. In the intervening years, it is assumed that this ratio declined annually at a constant rate.

Cuba's Net National Product in current year pesos comes from Mitchell (1993). These NNP values are converted to 1990 US dollars with the help of the peso-dollar exchange rate given in Taylor (2000) and the American historical consumer price index given in John McCusker, How Much Is That in Real Money (Worcester, Mass.: American Antiquarian Society, 1992), pp. 330-2.

A trend for Egyptian GDP per capita is calculated with the help of benchmark values given in 
Maddison (1995). Annual GDP per capita estimates are then calculated under the assumption that Egypt deviated from the Maddison-estimated Egyptian benchmark trend in the same way (percentage-wise) as Turkey did from her GDP per capita trend (after the civil war).

Figures for Portugal come from das Neves (1994). The GDP figures given in both current and 1914 constant escudos are converted to 1990 US dollars using the escudo-dollar exchange rate given in Taylor (2000) and the American historical price index in McCusker (1992).

GDP for Uruguay is taken from Mitchell (1993) for the period 1935-1940. Annual GDP per capita estimates for 1914-1934 are calculated by assuming that Uruguay deviated from her GDP per capita trend (between the benchmark years of 1914, found in Clemens and Williamson (2000), and 1935, found in Mitchell) in the same way that Argentina did.

\section{Share of Primary Product Exports in Total Exports}

This variable denotes the fraction of total export values consisting of "primary products" (defined below). Viewed as an indicator of the relative endowment of natural resources, it was made popular by Jeffrey Sachs and Andrew Warner, "Natural Resource Abundance and Economic Growth,” NBER Working Paper 5398, National Bureau of Economic Research, Cambridge, Mass. (December 1995). They defined "primary products" as those commodities falling into categories $0,1,2,3,4$, and 68 of the United Nations Standard International Trade Classification (SITC) Revision 1. These categories are, respectively: food and live animals, beverages and tobacco, crude materials excluding fuels, mineral fuels, animal or vegetable oils and fats, and non-ferrous metals. We use a slightly different definition of primary products, namely categories I, II, and III, of the Brussels 1913 Commodity Classification (recorded in Conference Internationale de Statistique Commerciale, Bruxelles, 1913: Documents et Proces-Verbaux, Establissements Generaux D’Imprimerie, Brussels, 1914). These categories are, respectively: live animals, food and drink, and raw materials or simply-prepared products. Thus, our definition of primary products includes all exports except categories IV (manufactured products) and V (money and specie). The only substantive differences between our definition of primary products and that of Sachs-Warner are that the former includes iron ore and excludes manufactured tobacco products like cigarettes and cigars.

Figures for the United States, Germany, France, Russia, Australia, Austria, Canada, Italy, Japan, Spain, Sweden, New Zealand, United Kingdom, and India come from the League of Nations, Industrialization and Foreign Trade (Geneva: Economic, Financial, and Transit Authority, 1945), pp. 15467. 
The sources of the figures for the remaining countries are the following: Argentina, Direccion General de Estadistica de la Nacion, El Comercio Exterior Argentino (Buenos Aires: various issues), 1925: pp. 26-30 and 1936: pp. 61-70; Brazil, Ministerio da Fazenda, Comercio Exterior do Brasil (Rio de Janeiro: various issues), 1929: pp. 62-83 and 1933: pp. 74-95; Burma, Report on the Trade and Customs Administration of Burma, 1937-38, (Rangoon: Government Printing and Stationery, 1938), p. 18, and Teruko Saito and Lee Kin Kiong, Statistics on the Burmese Economy (Singapore: Institute of Southeast Asian Studies, 1999), p. 181; Ceylon, Thirty Years of Trade Statistics of Ceylon, 1925-1954, (Colombo: Department of Commerce, Government Press, 1955), pp. 29-33; Chile, Estadistica Chilena (Santiago: Direccion General de Estadistica, various issues), 1928: p. 40 and 1935: p. 17; China, Yu-Kwei Cheng, Foreign Trade and Industrial Development in China (Westport, Conn: Greenwood Press Publishers, 1956), p. 35. Articles labeled as "semi-manufactured products" by Cheng are assumed to be primary products; Colombia, Departamento de Contraloria, Anuario Estadistico de Comercio Exterior (Bogota: 1929), pp. 17-20 and Contraloria General de la Republica, Comercio Exterior de Colombia (Bogota: 1937), pp. 4-11; Cuba, Secretaria de Hacienda, Comercio Exterior (Havana: various issues), 1926: p. IX, and 1946: p. 11; Denmark, Danmarks Vareinforsel og - Udforsel, 1925 and 1935 (Copenhagen: Danmarks Statistik, Department of Statistics, 1926 and 1936), 1925: p. 8, 1935: p. 8; for Egypt and Indonesia, figures are obtained through geometrical interpolation between the benchmark value in 1914, given in Clemens and Williamson (2000), and the benchmark value in 1954, found in the United Nations Yearbook of International Trade Statistics 1955 (Statistical Office of the United Nations, Department of Economic and Social Affairs, New York, 1956). Interpolation over such a long period of time seems justified because for both countries in question, the figures for 1914 and 1954 are very similar; Greece, M. Dorizas, The Foreign Trade of Greece (Philadelphia: University of Pennsylvania PhD thesis, 1925), Appendix 2; Mexico, Anuario de 1930 (Mexico D. F.: Departamento de Estadistica Nacional, Tacubaya, 1932), p. 442 and Secretaria de la Economia Nacional, Anuario Estadistico de los Estados Unidos Mexicanos 1939 (Mexico D. F.: 1941), p. 578; Norway, figures are estimated using the following sources: Values of export of manufactured and primary products in 1913 are found in Norway Foreign Trade (Oslo: The Trade Intelligence Bureau of Norway, 1923), p. 11. An index of the exports of manufactures in 1913-1930 is given in Norwegian Trade Review (Oslo: A.S Norwegian Publications), March 1931, vol. 2, no. 3, p. 68. These two sources are combined to estimate the value of primary product exports. Primary product exports are then divided by the value of total exports, reported in Banks (1976); Peru, Ministerio de Hacienda y Comercio, Comercio Especial del Peru (Callao: Estadistica General de Aduanas, 1926), p. 
XXIV) and Anuario del Comercio Exterior del Peru (Callao: Departamento de Estadistica General de Aduanas, 1936), unnumbered page; Portugal, Ministerio das Financas, Anuario Estatistico de Portugal (Lisbon: various issues), 1926: p. 214 and 1936: p. 376; the Philippines, O. M. Butler, The Philippines Islands: A Commercial Survey (Washington, D. C.: U. S. Department of Commerce, Trade Promotion Series, vol. 52, 1927), p. 116; Thailand, Annual Statement of the Foreign Trade and Navigation of the Kingdom of Siam (Bangkok: Department of His Majesty's Customs, 1935-36), pp. 163-71; Turkey, U. S. Department of Commerce, Turkey, Commercial and Industrial Handbook (Washington, D. C.: Government Printing Office, 1926), p. 179; Uruguay, Anuario Estadistico de la Republica Oriental del Uruguay (Montevideo: Imprenta Nacional, Montevideo, various issues), 1927: p. 213 and 1936: p. 215; Yugoslavia, U. S. Department of Commerce, Kingdom of Serbs, Croats, and Slovenes (Yugoslavia), a Commercial and Industrial Handbook (Washington, D. C.: Government Printing Office, 1928), p. 225.

For every country, missing values are estimated by geometric interpolation between the primary product export fractions at benchmark years.

\section{Export Share}

Export Share is calculated as the ratio of exports to national income. GDP is used in the denominator, and its sources can be found above. Data for exports (in current US dollar equivalents) come from Banks (1976), except for Burma, Ceylon, Egypt, India, Indonesia, the Philippines, Portugal, and Uruguay. The export figures given in Banks in current US dollars are converted to 1990 US dollars using the American historical consumer price index in McCusker (1992). Export data for the years 1914-1918 are obtained by geometric interpolation. Dividing these interpolated export figures by GDP gives the openness ratios for the war-time years.

Export figures for Ceylon, Egypt, India, Indonesia, the Philippines and Uruguay are found in Mitchell (1998). The export figures given in current national currency units in Mitchell are converted to 1990 US dollars using the exchange rates in Taylor (2000) and the American historical consumer price index in McCusker (1992). Once converted to 1990 US dollars, the export data for India, Indonesia, and the Philippines are divided by Maddison's (1995) GDP estimates to get the openness variable. The calculation of Ceylon, Egypt, and Uruguay's per capita GDP has already been described. Per capita GDP figures for these three countries were multiplied by their population estimates to get GDP. Exports were then divided by these GDP levels to get the openness ratio of Ceylon, Egypt, and Uruguay.

To calculate openness for Burma, we rely on Saito and Kiong (1999), who provide estimates of 
Burmese Net Domestic Product and exports in current rupees until 1938. For Portugal, export and GDP figures in current escudos are taken from das Neves (1994).

\section{Effective Distance from Trading Partners}

Effective Distance from trading partners is calculated as the product of two quantities. The first quantity is the average distance from the capital city of the country in question to the capital cities of its principal trading partners, weighted by the value of exports going to each of those partners in the year in question. Distances are taken from the Microsoft Excel Worksheet prepared by Howard Shatz's unpublished data (Cambridge: Harvard University Center for International Development, 1997), which gives them in miles between 254 (mainly capital) cities of the world using the great circle formula. The second quantity is an index of tramp shipping freight charges (per distance and weight) shown in Table VIII (p. 122) of L. Isserlis, “Tramp Shipping Cargoes, and Freights," Journal of the Royal Statistical Society, 101, 1 (1938): pp. 53-146. Distance from the closest world export center is multiplied by this shipping freight index. Note that the Isserlis index only offers an estimate of changes in global transportation costs which is generic to the world as a whole. By using it, we only control for differences in transportation costs over time, not across space. The later are not yet available on the comprehensive scale that this data set demands.

\section{Energy Consumption per Capita}

As is common in historical studies with limited endowment data, energy consumption per capita is used as a proxy for capital-labor ratios. For most countries, energy consumption in kilograms of coal equivalent per capita from the year 1919 onwards is taken from Banks (1976).

Data for Burma, Ceylon, China, India, Indonesia, and Philippines come from the United Nations, World Energy Supplies in Selected Years, 1929-1950 (New York: Statistical Papers, Series J, no. 1, 1952), pp. 64-6, where per capita consumption of commercial uses of energy is reported in metric tons for benchmark years between 1929-1950. Figures for missing years between the benchmark values are obtained by geometric interpolation. Figures for 1914-1928 for these six countries only are estimated as a linear function of population, GDP per capita, openness, population growth, primary product exports as a fraction of total exports, primary school enrollment as a fraction of population below age 14, land area, and railroad mileage per capita. The prediction function is calibrated for each country using known energy consumption during 1929-1950, when it performs extremely well, and is assumed valid for 1914-1928 as 
well. The same prediction function was applied to Egypt in the absence of calibrating data, there being little reason to believe that Egyptian energy usage patterns during this period were radically different from peer countries.

\section{Infant Mortality}

Infant mortality denotes the number of deaths of infants under one year old per 1000 live births, and they are taken from the appropriate edition of Mitchell's International Historical Statistics (1992, 1993, 1998) for every country except six —Brazil, Burma, China, Indonesia, Thailand, and Turkey. Figures are collected for the entire period of 1865-1940, but for some countries data are not available all the way back to 1865. For the period 1921-1938, figures for Burma, Thailand, and Turkey come from the League of Nations, Statistical Year-Book of the League of Nations (Geneva: League of Nations Economic Intelligence Service, 1941). In case of Thailand, 1921-1935 data for the "straits settlements" (comprising roughly modern-day Malaysia) are used as a proxy; after 1936 unproxied Thai figures come from Wilson (1983), p. 46. For Turkey, the average of Greece, Yugoslavia and Egypt is used for benchmarks, and for the missing Turkish years in between those benchmarks, the trend for Egypt is assumed.

Figures for Brazil are taken from Ludwig (1985), p. 84. The unweighted average of the infant mortality rates of several urban counties is used to estimate Brazil's overall infant mortality rate.

Infant mortality rates for Peru come from Mitchell (1993) from 1940 onwards only. Before 1940, Peru is assumed to follow Colombia's trend.

Figures for China are estimated by India's infant mortality rates, while the infant mortality rates of the Philippines are used as a proxy for Indonesia.

\section{Inflation}

Inflation is calculated as the annual percentage change in the Consumer Price Index (CPI) of each country. The annual change in the CPI for most countries is given in Taylor (2000). Inflation figures are collected for the period 1865-1940. However, figures in Taylor's database do not reach back all the way to 1865 for every country.

Figures for Burma are estimated by using the Burmese cost of living index in the United Nations Statistical Yearbook 1949-50 (New York, 1950) p. 402 and the Indian CPI given in Taylor (2000).

Figures for the Philippines are estimated using the cost of living index given in the United Nations Statistical Yearbook 1949-50 (New York, 1950), p. 403 and the Yearbook of Philippine Statistics 
(Manila: Bureau of the Census and Statistics, Republic of the Philippines, 1947), p. 251; augmented by the cost of living trends for China, India, and Japan reported in the United Nations Statistical Yearbook 194950 , and by the retail and wholesale price trends for China, India, Indonesia, and Japan in the Statistical Year-Book of the League of Nations (Geneva: various issues), 1931/32: pp. 312-21 and 1938/39: pp. 2316.

Cuban inflation is estimated using the following pieces of evidence: the index of the cost of food in Cuba given in the Anuario Estadistico de Cuba de 1952 (Havana: Ministerio de Hacienda, Republica de Cuba), p 285; the Cuban cost of living index from the United Nations Statistical Yearbook 1949-50, p. 401; and annual changes in the CPIs of Argentina, Brazil, Chile, Colombia, Mexico, and Peru taken from Taylor (2000).

Inflation for Ceylon are estimated using the export and import price indices, the terms of trade index, and the working class cost of living index for Ceylon given in Thirty Years Trade Statistics of Ceylon (1925-1954), Part IV (Colombo: Government Press, 1957), p.1901.

Inflation for Thailand is calculated as the annual percentage change in the wholesale food price index, taken from Wilson (1983), p. 322.

Inflation for Indonesia is calculated from the Consumer Price Index given in Mitchell (1993).

Inflation for Portugal is estimated with the annual change of the GDP deflator given in das Neves (1994), pp. 193-7.

For Colombia, figures for 1917-1924 come from Mitchell (1993), while figures for the rest of the period are taken from Taylor (2000).

\section{Land-Labor Ratio}

The land-labor ratio is calculated by dividing total area of arable (food) crops in hectares by labor force.

Estimates for the sixteen countries consisting of Argentina, Australia, Canada, Uruguay, USA, UK, Denmark, Sweden, France, Germany, Spain, Egypt, Thailand, India, Burma, and Japan are taken from the database underlying the analysis in J. G. Williamson, "Land, Labor and Globalization in the PreIndustrial Third World," NBER Working Paper 7784, National Bureau of Economics Research, Cambridge, Mass. (July 2000) where they are described in an appendix. The method, however, is the same as that described below for the remaining 19 countries.

Estimates for the nineteen countries consisting of Austria, Brazil, Ceylon, Chile, China, Colombia, 
Cuba, Greece, Indonesia, Italy, Mexico, New Zealand, Norway, Peru, Philippines, Portugal, Turkey, USSR, and Yugoslavia were calculated in the following way: Total area of arable crops (in hectares) are taken from the appropriate edition of Mitchell's International Historical Statistics $(1992,1993,1998)$. The labor force is estimated by the population between the ages 15 and 64. The fraction of the population between ages 15 and 64 are calculated from Mitchell (1992, 1993, 1998), but provided for census years only. The fraction 15-64 was then multiplied by the total population in the census years to get benchmark estimates of the each country's labor force, and thus the land-labor ratio. Land-labor ratios for the missing years between the benchmarks are estimated by geometric interpolation.

\section{School Enrollment Rate}

Two variables are used to measure the primary school enrollment rates for those of school age. The first variable is primary school enrollment per capita. The second is the population share under the age of 14. Each variable is described in turn.

Per capita primary school enrollment rates for most countries are taken from Banks (1976), and war-time years (1914-1918) are geometrically interpolated.

Primary school enrollment for Burma, Ceylon, Egypt, India, Indonesia, and the Philippines are from Mitchell (1998). These figures are then divided by the size of the population of each country, in order to arrive at per capita school enrollment. Figures for Ceylon denote primary and secondary school enrollment per capita combined. (It is assumed that secondary enrollment is a tiny fraction of total school enrollment in Ceylon.)

Primary school enrollment figures for Australia are from Peter H. Lindert, "Democracy, Decentralization, and Mass Schooling Before 1914: Appendices," Working Paper 105, Agricultural History Center, University of California at Davis (2001), pp. 11-12. Missing years are geometrically interpolated.

Primary school enrollment rates for those of school age are calculated by dividing per capita primary enrollment rates by the fraction of the population under the age of 14 . The fraction of the population under the age of 14 is calculated from the appropriate editions of Mitchell $(1992,1993,1998)$, where the population distributions by age are provided for census years. The youth dependency ratios (i.e. fraction of the population under the age of 14) for missing years are obtained by geometric interpolation.

\section{Railroad Mileage}


Railroad mileage, defined as miles of line (public and private) rather than miles of track, is taken from Banks (1976), and war-time years (1914-1918) are geometrically interpolated.

\section{Land Area}

Land area, excluding non-contiguous colonies, and in thousands of square miles, is taken from Banks (1976). Where a country's borders were changed during World War I, we assume that the change took place in 1919. In the case of Australia, Burma, Ceylon, Cuba, Egypt, India, Indonesia, New Zealand, Philippines, and Serbia, where Banks (1976) does not report land area for the beginning of our observed period, land area is assumed to be unchanged going back to 1865 .

\section{Terms of Trade}

Terms of trade figures for 1870-1940 for Argentina, Australia, Burma, Canada, Denmark, Egypt, France, Germany, India, Japan, Spain, Sweden, Thailand, United Kingdom, Uruguay, and USA are taken from the database underlying Williamson (2000). However, these figures were converted from the base year 1911, to 1900 .

For countries not covered in Williamson, terms of trade figures for 1865-1914 are taken from Clemens and Williamson (2000). Missing years for Argentina, Burma, Germany, and Sweden are filled in from Clemens and Williamson as well.

\section{Exports to Main Trading Partners}

This variable denotes the value of exports (in current national currency units) to a country's main trading partners. Figures for every country are presented in the appropriate editions of Mitchell (1992, 1993, 1998).

\section{Trading partner tariffs and growth}

The index of tariffs in principal trading partners is calculated as the weighted average of own tariffs in the four or five countries to which the country in question exported the largest absolute value of goods (for three countries_Colombia, New Zealand, and the Philippines—only the top three trading partners are covered). The weights are the absolute value of exports that went to each of said partners. These partner export figures are taken from Mitchell op. cit. In all cases, the vast majority of each country's exports are accounted for by exports to these principal trading partners. The index of growth in 
principal trading partners is calculated in identical fashion.

\section{PART II: AFTER 1950}

\section{Import Duties over Imports}

After 1970, these are taken from the World Bank's World Development Indicators 2000 CDROM. Prior to 1970 and in cases of missing numbers for 1970-75 in the World Bank data, they are taken from the United Nations Statistical Yearbook, "Public Finance" and "External Trade" sections, 1951, 1957, 1963, 1967, 1973, and 1977, Statistical Office of the United Nations, Dept. of Economic and Social Affairs, New York. In all cases the United Nations data are collected until a sufficiently late year as to provide significant overlap with the World Bank numbers, to ensure that the two series matched up well at the interface. Since European Union tariffs are collected by a central authority, customs revenue to national governments trends quickly towards zero when countries join the EU. For this reason, the ratio of import duties to imports for the entire EU is applied to each member country starting from the year it joined the Union.

\section{Effective Distance}

Physical distance comes from Shatz op. cit., and is multiplied by an index of transportation costs to calculate "effective distance" exactly as described in the pre-1950 section. The index of transportation costs is calculated using data provided by David Hummels which are described in David Hummels 1999, "Have International Transportation Costs Declined?" Mimeo, University of Chicago (as of this writing he has relocated to Purdue University). A worldwide index of transportation costs is constructed as a weighted average of Hummels' air and ocean shipping cost indices, weighted by the fraction of world trade going by each mode of transportation in each year.

\section{Trading Partners}

Exports from every country in the world to every other country in the world, 1950-1997, are taken from the Direction of Trade database published by the International Monetary Fund (IMF, Direction of Trade Statistics, 1948-1997, [C omputer File], ICPSR ed. (A nn A rbor, M ichigan: Inter-U niversity Consortium for Political and Social Research, 1998)). These export values, for each country in each year, are used as weights when calculating the average OPENness of trading partners, average effective distance 
to trading partners, average GDP growth among trading partners, and average trading partner tariffs.

\section{Other regressors}

Population, natural population growth and immigration figures are taken from the United Nations Demographic Yearbook, Historical Supplement 2000 on CD-ROM. Primary school enrollment, the fraction of the population below age 15, and the dependency ratio (the ratio of the population aged below 15 or above 64 to the population between the ages of 15 and 64) are taken from World Bank's World Development Indicators CD-ROM 2000. Real exchange rates and Terms of Trade are taken from the International Monetary Fund's International Financial Statistics CD-ROM 2000. Real GDP per capita comes from the Summers and Heston dataset (Penn World Tables v6.0, 2001, Center for International Comparisons, University of Pennsylvania, Philadelphia. Available at http://pwt.econ.upenn.edu). 